\title{
Groundwater flow modelling in the central zone of Hanoi, Vietnam
}

\author{
Simon Jusseret • Vu Thanh Tam • Alain Dassargues
}

\begin{abstract}
On the basis of a review of the Quaternary sedimentary architecture in the area of Hanoi city (Vietnam), a numerical, deterministic and three-dimensional groundwater flow model has been built for a simulation between 1995 and 2004. The sedimentary architecture has been constructed on the basis of the data from 32 drillings covering the entire Quaternary sequence (but with little sedimentological detail), as well as hydrographical and hydrogeological data. Both steady- and transient-state conditions were tested. Results calculated by the model seem to indicate that the conceptual hypotheses adopted are reasonable for the modelled domain and period. The simulation allows for calculation of the regional groundwater flow trends. It is also used for assessing the relative importance of the various recharge sources of the shallow aquifer system in Hanoi, and for estimating the interactions between groundwater and the Red River.
\end{abstract}

Keywords Vietnam · Conceptual models - Shallow aquifers · Groundwater/surface-water relations · Numerical modelling

Received: 10 June 2008 / Accepted: 4 December 2008

(C) Springer-Verlag 2009

S. Jusseret $\cdot$ A. Dassargues

ArGEnCo Department,

Université de Liège, Hydrogeology and Environmental Geology, Liège, Belgium

S. Jusseret ( $\bullet)$

Aspirant du F.R.S. FNRS,

Department of Archaeology and Art History,

Université Catholique de Louvain,

Place Blaise Pascal, 1, 1348 Louvain-la-Neuve, Belgium

e-mail: Simon.Jusseret@uclouvain.be

V. T. Tam

Ministry of Natural Resources and Environment (MONRE),

Center for Water Resources Planning and Investigation (CWRPI), Hanoi, Vietnam

A. Dassargues

Department of Earth and Environmental Sciences,

Division Geology,

Katholieke Universiteit Leuven, Leuven, Belgium

\section{Introduction}

Though already studied in relation to subsidence processes (Thu and Fredlund 2000), the hydrogeological setting of the area of the city of Hanoi, Vietnam is still scantily understood. This observation is especially true where basic information related to regional groundwater flow trends, to recharge processes and to the link between the geological setting and the observed groundwater levels is considered. This gap is here bridged through the construction of a physically based groundwater flow model of the shallow aquifer system in the Hanoi city area. This tool is constructed on the basis of a comprehensive sedimentological model (Jusseret, S., Université de Liège, Université Catholique de Louvain; Baeteman, C., Belgian Geological Survey; Dassargues, A., Université de Liège, Katholieke Universiteit Leuven; "The stratigraphical architecture of the Quaternary deposits as support for hydrogeological modelling of the central area of Hanoi (Vietnam)", unpublished report, 2008). Similar works linking sedimentological modelling with hydrogeological purposes in unconsolidated sediments are presented by Bonomi (2009), Foreman and Sharp (1981), Hanson et al. (2002, 2003, 2004), Huggenberger and Regli (2006), McMahon et al. (2000), Ponti et al. (2007), Faunt et al. (2008), Sharpe et al. (2003) and Yong et al. (1995).

\section{Hydrogeological context}

The city of Hanoi lies in the Red River delta (Funabiki et al. 2007; Haruyama et al. 2001; Hori et al. 2004; Mathers et al. 1996; Mathers and Zalasiewicz 1999; Saito et al. 2004; Tanabe et al. 2003a, b, 2006). The studied area includes the demographical and historical center of Hanoi and covers $63 \mathrm{~km}^{2}$, with a perimeter of $36 \mathrm{~km}$ (Fig. 1). The studied area is bordered northwards and eastwards by the Red River for a distance of about $18.3 \mathrm{~km}$. The western border is parallel to the course of the Nhue River for about $4 \mathrm{~km}$ and can be located $700 \mathrm{~m}$ east of it. The modelled area includes several lakes of which the main ones are the West Lake $\left(5.2 \mathrm{~km}^{2}\right)$ and the White Silk Lake $\left(0.2 \mathrm{~km}^{2}\right)$. The Hoan Kiem Lake, located in the old quarters of Hanoi, covers about $0.1 \mathrm{~km}^{2}$.

Sedimentological cross-sections and profile type map as proposed by Jusseret et al. (as previously given; "The stratigraphical architecture of the Quaternary deposits as 


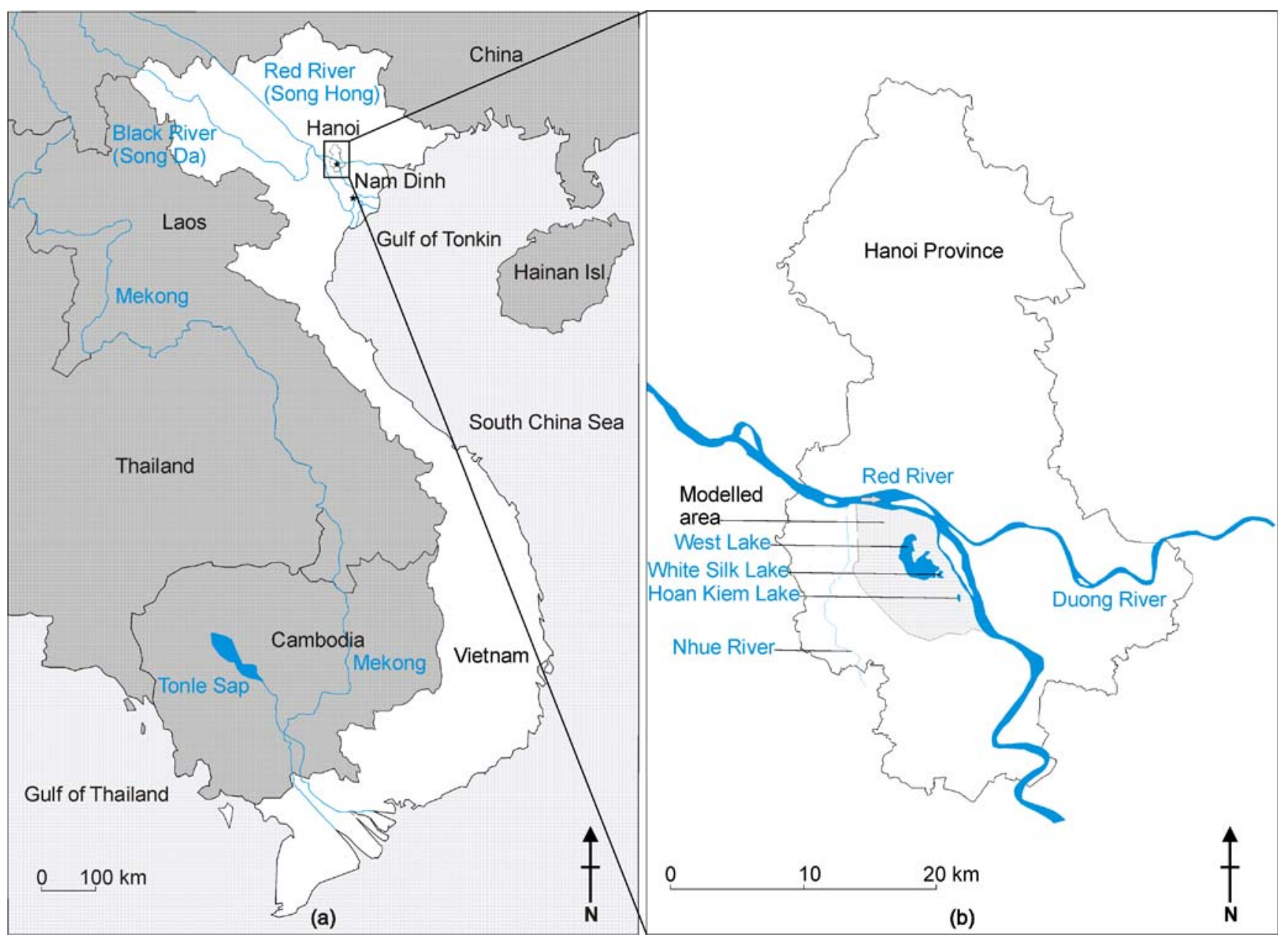

Fig. 1 a Location of Hanoi and its eponymous province in Vietnam. b Location of the modelled area (light grey) in the Hanoi province

support for hydrogeological modelling of the central area of Hanoi (Vietnam)", unpublished report, 2008), as well as piezometric time series, are here exploited for defining the general hydrogeological context in the central zone of Hanoi.

The sedimentological description highlighted the relationship between the genesis of the sedimentary deposits in Hanoi and their hydrogeological role: coarse sediments (gravels and sands) can be found in channel structures and act as aquifers, while alluvial ridge silts and clays act as low-permeability units. Depending on the spatial relationship between those units, aquifers present a confined or unconfined character.

The profile type map (Fig. 2) is useful for spotting the spatial distribution of the aquifer Holocene channels. These units are separated from each other by clayey deposits, which also isolate them from the underlying Pleistocene aquifer. Holocene channels only outcrop where an active alluvial system is present, which implies that the Holocene aquifers are predominantly covered by a silty clayey layer and therefore defined as semi-confined.

Comparison between the Pleistocene and Holocene groundwater piezometric heads, as well as Red River water levels (measuring stations located on Fig. 3) seems to indicate the existence, close to the river, of a hydraulic equilibrium between Holocene and Pleistocene aquifers on the one hand and the Red River on the other hand. Further from the river's west side, the groundwater piezometric head is lower than the observed Red River water level, regardless of the time of the year (time period covered by the available data: 1995-2004). This observation confirms the forced-gradient conditions due to the influence of the groundwater pumping wells in the study area. One can further observe an increasing difference between Holocene and Pleistocene groundwater levels (from about $7 \mathrm{~m}$ in January 1995 to more than $10 \mathrm{~m}$ in December 2004 at P12, see Fig. 3) together with the distance to the Red River. Moreover this time evolution can be related to the increasing pumping rates encountered in Hanoi during the last 15 years (see also Nguyen and Helm 1998; Thu and Fredlund 2000).

According to the previous discussion, the Pleistocene aquifer can be considered as unconfined close to the Red River, where the groundwater and Red River water levels are similar. In other zones, the Pleistocene aquifer can be considered as unconfined in outcropping areas and confined elsewhere. Even in these zones, the actual lowering of the groundwater levels between 1995 and 


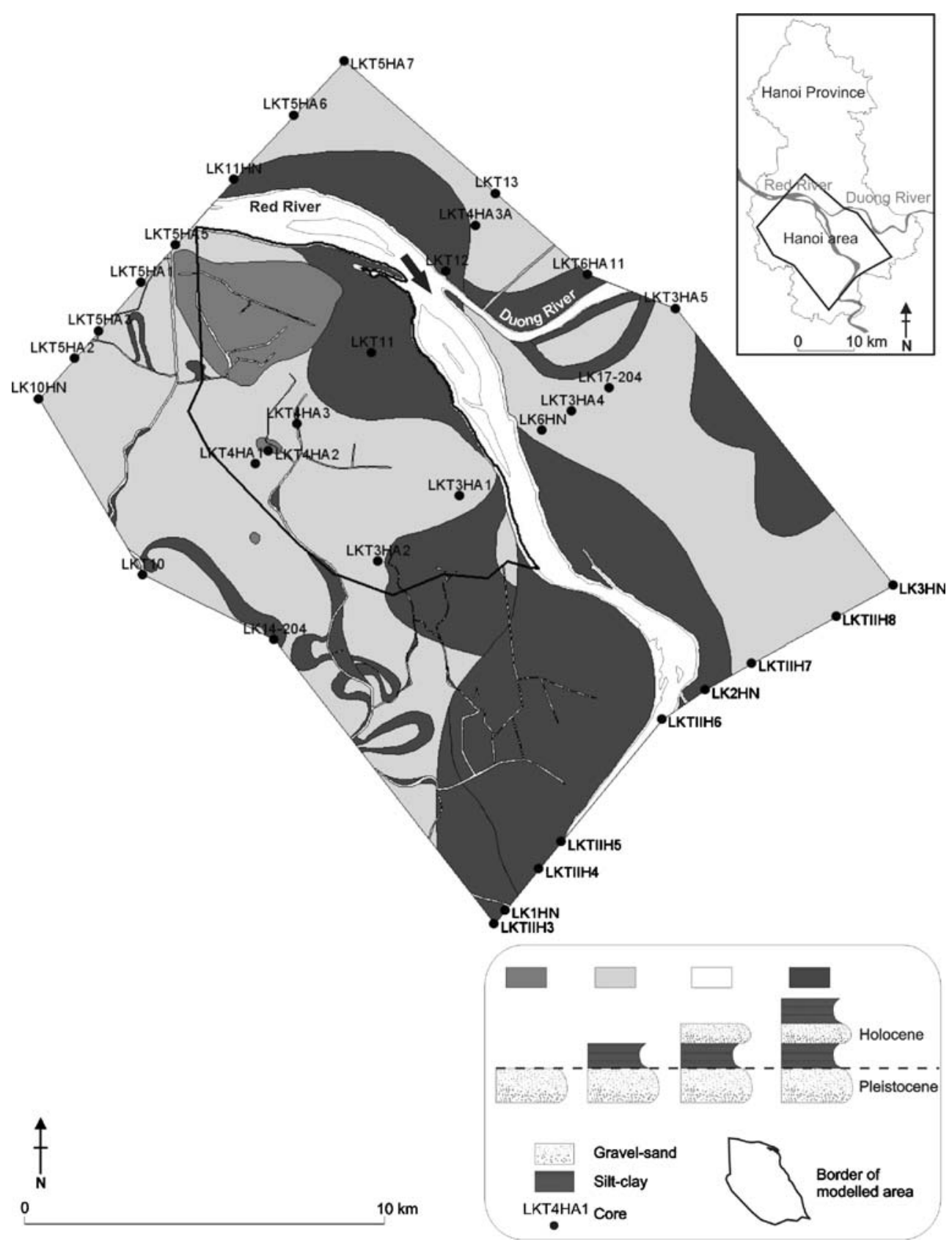

Fig. 2 Profile type map of the Hanoi area

2004 leads to a semi-confined character if one considers the spatial complexity of the low permeability layers.

The Holocene groundwater levels are generally higher than those of the Pleistocene. This implies that groundwater is likely to seep from the phreatic Holocene aquifers through the basal Holocene silty clayey sediments and hence, participate to the recharge of the Pleistocene aquifer.

These basic observations are in this contribution completed by the results provided by a three-dimensional heterogeneous groundwater flow model. These results are related to the recharge processes, the variation through time of the regional flow trends and the link between groundwater levels and the spatial distribution of the Quaternary sedimentary bodies.

\section{Materials and method}

The data at disposal for the completion of this study are all part of a database gathered by the Research Institute of Geology and Mineral Resources (Research Institute of Geology and Mineral Resources (2006), Unpublished database) of Hanoi. All water levels mentioned are given in comparison with the mean sea level taken as a fixed reference. In this section, the available data are first 


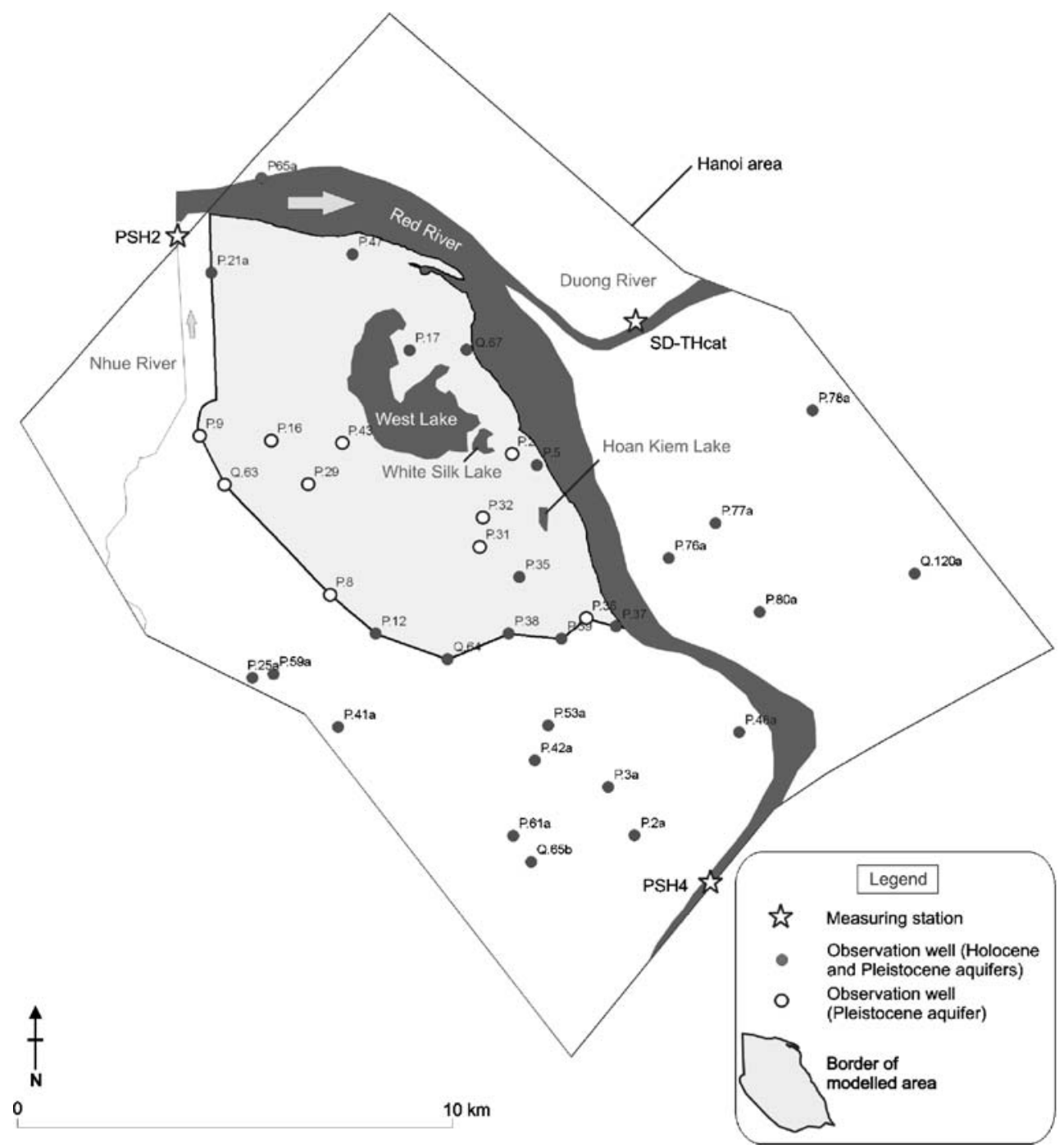

Fig. 3 Observation wells and river level measuring stations inside and close to the modelled area

presented and the method, detailing the conceptual choices made and the implementation process, is then discussed.

\section{Materials}

1. Profile type map, sedimentological cross-sections and panel diagrams (Jusseret et al., as previously given, "The stratigraphical architecture of the Quaternary deposits as support for hydrogeological modelling of the central area of Hanoi (Vietnam)", unpublished report, 2008)

2. Monthly water levels of the Red River and the Duong River (Fig. 1) at three measuring stations, for the 19952004 period: PSH2, SD-THcat and PSH4 (Fig. 3)

3. Monthly piezometric levels at 21 observation wells inside the modelled area, for the 1995-2004 period (Fig. 3)

4. Monthly precipitation and potential evapotranspiration data for the 1995-2004 period

5. Hydraulic conductivities $(K)$ and storage coefficients $(S)$ for the Pleistocene and Holocene aquifers (Tables 1, 2, 3, 4 and 5)
6. Pumping rates at 12 public pumping fields (Table 6), related to an unknown period but after 2000 (V.T. Tam, MONRE, personal communication, 2006)

7. General evolution of the pumping rates between the 1990 s and the 2000s for the previously mentioned pumping fields

8. Estimation of the total pumping rate related to private wells, expressed as a fraction of the total rate pumped by public fields

Table 1 Interpreted hydraulic conductivity $(K)$ values for the pumping tests carried out in depth-averaged conditions in the Holocene aquifers located in the modelled area (corresponding tests located on Fig. 8)

\begin{tabular}{ll}
\hline Pumping test & $K(\mathrm{~m} / \mathrm{s})$ \\
\hline TD7k & $3 \mathrm{E}-04$ \\
CD10-1 & $2 \mathrm{E}-04$ \\
$54 \mathrm{e}$ & $1 \mathrm{E}-04$ \\
$44 \mathrm{c}$ & $2 \mathrm{E}-04$ \\
T37 & $2 \mathrm{E}-04$ \\
VC & $6 \mathrm{E}-04$ \\
\hline
\end{tabular}


Table 2 Interpreted storage coefficient $(S)$ values for the pumping tests carried out in depth-averaged conditions in the Holocene aquifers located in the modelled area (corresponding tests located on Fig. 8)

\begin{tabular}{ll}
\hline Pumping test & $S(-)$ \\
\hline $54^{\mathrm{e}}$ & $1.0 \mathrm{E}-01$ \\
TD7k & $1.2 \mathrm{E}-01$ \\
CD10-1 & $3 \mathrm{E}-02$ \\
$44 \mathrm{c}$ & $3 \mathrm{E}-02$ \\
VC & $1.7 \mathrm{E}-01$ \\
\hline
\end{tabular}

\section{Method}

\section{Conceptual model}

The sedimentological heterogeneity of the studied area discussed in the introduction, as well as the awaited occurrence of significant vertical flow components (interactions between aquifers, drawdown caused by pumping wells), require a three-dimensional simulation of the groundwater flows. The lateral boundary of the study area is divided up into four sections (Fig. 4). Geometrically, it corresponds to the following boundaries and boundary conditions (in a clockwise direction) starting from north.

The Red River boundary from north to east, corresponding to a prescribed piezometric head (Dirichlet condition). The corresponding water levels are those of

Table 3 Interpreted hydraulic conductivity $(K)$ values for the pumping tests carried out in depth-averaged conditions in the Pleistocene aquifer located in the modelled area (corresponding tests located on Fig. 8)

\begin{tabular}{|c|c|}
\hline Pumping test & $K(\mathrm{~m} / \mathrm{s})$ \\
\hline CD17 & 5 E-04 \\
\hline CD15 & 7 E-04 \\
\hline 10aNSL & 5 E-04 \\
\hline TD13 & 4 E-04 \\
\hline TD7 & $6 \mathrm{E}-04$ \\
\hline LY9 & 8 E-04 \\
\hline MD10 & 4 E-04 \\
\hline TD4 & 7 E-04 \\
\hline TD8 & 7 E-04 \\
\hline 18aYP-TD & 3 E-04 \\
\hline $54 \mathrm{TD}$ & 3 E-04 \\
\hline H36YP & $6 \mathrm{E}-04$ \\
\hline H42YP & 8 E-04 \\
\hline TDCD9 & $8 \mathrm{E}-04$ \\
\hline TDCD13 & 7 E-04 \\
\hline TDCD17 & 3 E-04 \\
\hline H31 & 5 E-04 \\
\hline CD10 & 4 E-04 \\
\hline CD12 & 7 E-04 \\
\hline 813 & 3 E-04 \\
\hline 46TD & $2 \mathrm{E}-04$ \\
\hline $50 \mathrm{TD}$ & 3 E-04 \\
\hline 48TD & 2 E-04 \\
\hline TD3 & 5 E-04 \\
\hline 5DT & 4 E-04 \\
\hline LY6A & $6 \mathrm{E}-04$ \\
\hline 45TD & 3 E-04 \\
\hline $44 c$ & 2 E-04 \\
\hline
\end{tabular}

Table 4 Interpreted storage coefficients $(S)$ for the pumping tests carried out in depth-averaged conditions in the Pleistocene aquifer covered by Holocene sediments

\begin{tabular}{ll}
\hline Pumping test & $S(-)$ \\
\hline 1 & $1 \mathrm{E}-03$ \\
2 & $2 \mathrm{E}-01$ \\
3 & $3 \mathrm{E}-04$ \\
4 & $3 \mathrm{E}-02$ \\
5 & $3 \mathrm{E}-03$ \\
6 & $3 \mathrm{E}-03$ \\
7 & $4 \mathrm{E}-05$ \\
8 & $6 \mathrm{E}-02$ \\
9 & $2 \mathrm{E}-02$ \\
10 & $2 \mathrm{E}-02$ \\
11 & $4 \mathrm{E}-04$ \\
12 & $4 \mathrm{E}-03$ \\
13 & $7 \mathrm{E}-02$ \\
14 & $5 \mathrm{E}-02$ \\
15 & $2 \mathrm{E}-02$ \\
16 & $9 \mathrm{E}-03$ \\
17 & $7 \mathrm{E}-02$ \\
18 & $4 \mathrm{E}-05$ \\
19 & $3 \mathrm{E}-03$
\end{tabular}

The number of the pumping test is indicative. The tests have been carried out throughout the province of Hanoi

the Red River, which are measured monthly at three stations (Fig. 3). The location of these stations leads to two possibilities for defining the Red River boundary condition. The first one considers the measurements given by stations PSH2 and PSH4. The observed values provided by the SD-THcat station are transferred to an intermediate point, equidistant from the two others. The variation of the water levels between two consecutive measuring points is considered as linear. The second way of defining the Red River boundary condition takes only into account the results given by the PSH2 and PSH4 measuring stations. The possible justification of this choice mainly comes from the location of the SD-THcat

Table 5 Interpreted storage coefficients $(S)$ for the pumping tests carried out in depth-averaged conditions in the outcropping Pleistocene aquifer

\begin{tabular}{ll}
\hline Pumping test & $S(-)$ \\
\hline 1 & $2 \mathrm{E}-01$ \\
2 & $3 \mathrm{E}-03$ \\
3 & $1 \mathrm{E}-03$ \\
4 & $2 \mathrm{E}-01$ \\
5 & $2 \mathrm{E}-01$ \\
6 & $2 \mathrm{E}-01$ \\
7 & $2 \mathrm{E}-01$ \\
8 & $2 \mathrm{E}-01$ \\
9 & $2 \mathrm{E}-01$ \\
10 & $2 \mathrm{E}-01$ \\
11 & $2 \mathrm{E}-01$ \\
12 & $2 \mathrm{E}-01$ \\
13 & $2 \mathrm{E}-01$ \\
14 & $2 \mathrm{E}-01$ \\
15 & $2 \mathrm{E}-01$ \\
16 & $6 \mathrm{E}-02$ \\
17 & $1 \mathrm{E}-02$ \\
\hline
\end{tabular}

The number of the pumping test is indicative. The tests have been carried out throughout the province of Hanoi 
Table 6 Mean rates pumped in the Pleistocene aquifer by the well fields located in the modelled area. The main fields (see Fig. 5) are indicated in capitals. All rates refer to a date after 2000

\begin{tabular}{ll}
\hline Pumping fields & $\begin{array}{l}\text { Mean pumping } \\
\text { rates }\left(\mathrm{m}^{3} / \text { day }\right)\end{array}$ \\
\hline CAO DINH & 29,997 \\
Don Thuy & 7,700 \\
LONG YEN & 36,756 \\
MAI DICH & 15,800 \\
NGOC HA & 44,410 \\
NGO SI LIEN & 49,368 \\
YEN PHU & 87,488 \\
Thuy Loi & 500 \\
Van Don & 5,200 \\
Phuc Tan & 3,000 \\
Lang Bac & 10,000 \\
Khuong Trung & 7,075 \\
TOTAL & 297,294 \\
\hline
\end{tabular}

station, close to the Duong River providing a measurement which could significantly differ from actual water levels in the Red River. For this second possibility, the measurements at PSH2 are directly allocated to the northwestern extremity of the Red River boundary. The observed values at PSH4 are "corrected" as a function of the mean gradient in the Red River before being imposed on the southeastern extremity of the boundary.

On the south boundary, a prescribed head (Dirichlet condition) is defined in every point of the Pleistocene and Holocene aquifer deposits cut by this boundary. The prescribed heads are provided by the piezometric time series from the P37, P36, P39, P38, Q64, P12, P8, Q63 and $\mathrm{P} 9$ observation wells, located at each extremity of the segments forming the south boundary. A prescribed impervious boundary (Neumann condition) is chosen, on the other hand, where the south boundary cuts less permeable silty clayey sediments.

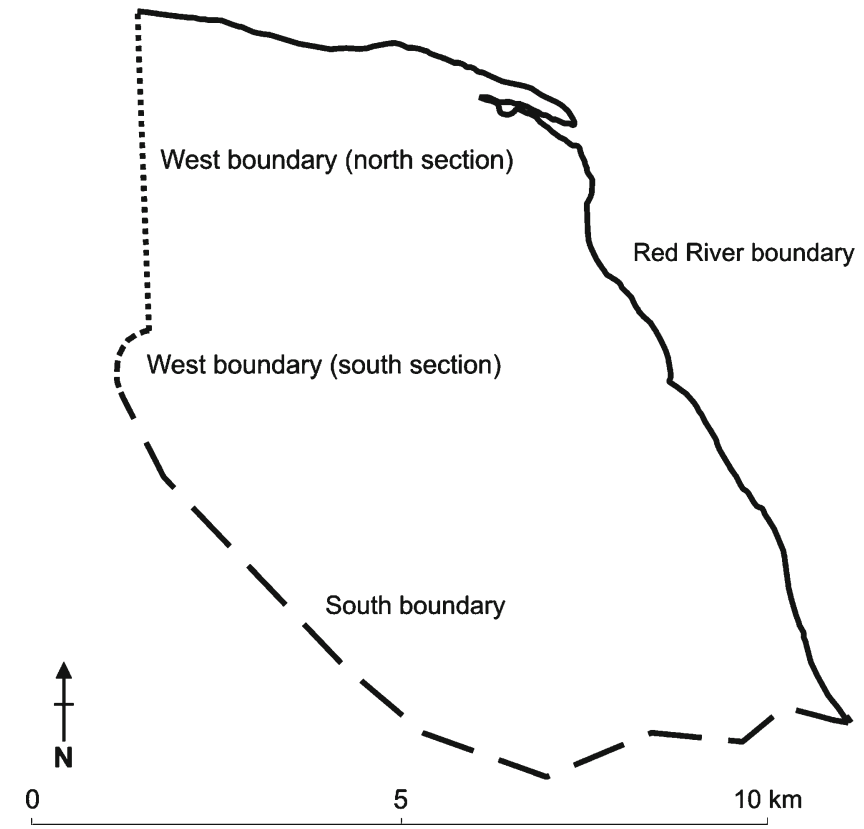

Fig. 4 Location of the four boundaries of the modelled area
On the west boundary-south section, a prescribed piezometric head is chosen and defined with the help of the piezometric chronicles related to the P9 observation well. Because the geometry of the south section of this west boundary is designed in a way to approach an equipotential line close to the Mai Dich pumping field (Fig. 5), the groundwater level imposed is the same in every point of this section.

The west boundary-north section is oriented perpendicularly to the Red River and to expected equipotential lines related to the Mai Dich pumping drawdown cone. A zero-flux condition can thus reasonably be chosen for this section. This Neumann condition is interrupted at the P21a well (located on the boundary), where a Dirichlet condition is imposed. The lower boundary of the model corresponds to the basis of the Quaternary sediments. A null flux (Neumann condition) is imposed in every point because the underlying Tertiary shales (Jusseret et al., as previously given, "The stratigraphical architecture of the Quaternary deposits as support for hydrogeological modelling of the central area of Hanoi (Vietnam)", unpublished report, 2008) are expected to have a very low permeability. The upper boundary condition will be discussed later, together with the conceptual choices related to the source and sink terms.

The combination of the sedimentological data (Jusseret et al., as previously given, "The stratigraphical architecture of the Quaternary deposits as support for hydrogeological modelling of the central area of Hanoi (Vietnam)", unpublished report, 2008) and the results of pumping tests are particularly useful to estimate the parameter values and spatial distribution of hydrogeological units (see Fogg et al. 1998; Foreman and Sharp 1981 and McCloskey and Finnemore 1996 for similar approaches).

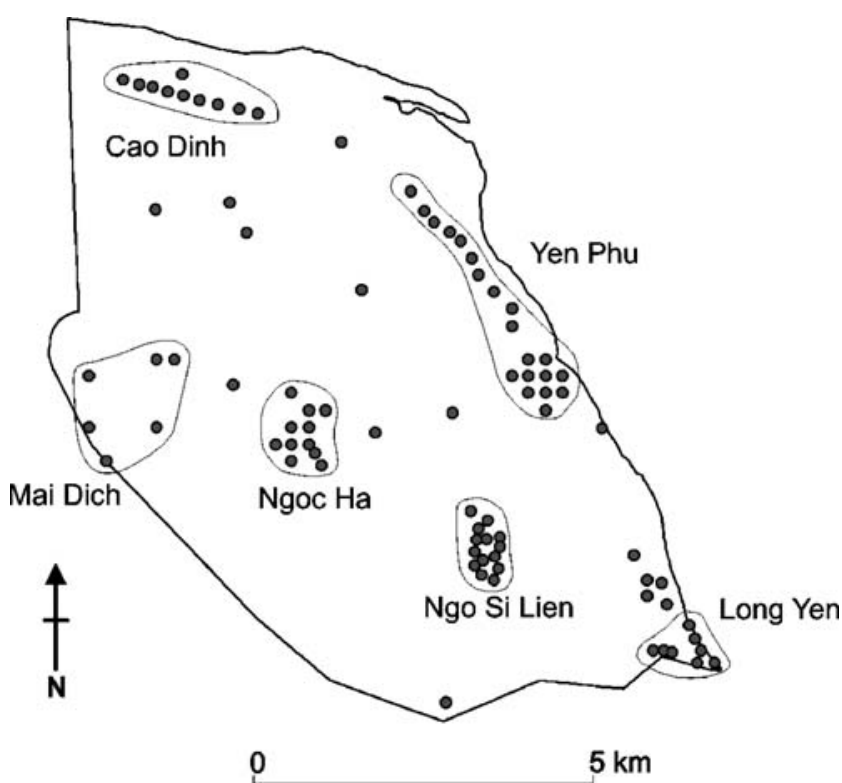

Fig. 5 Location of the main pumping fields situated in the modelled area (circles represent wells) 
Three different types of geological materials characterize the Quaternary sediments: gravels, sands and silts-clays (Jusseret et al., as previously given, "The stratigraphical architecture of the Quaternary deposits as support for hydrogeological modelling of the central area of Hanoi (Vietnam)", unpublished report, 2008). The hydrogeological properties of these materials are known on the basis of pumping tests interpretation. The corresponding tests have been carried out with wells screened throughout the entire thickness of the considered aquifer. The data related to hydraulic conductivities and storage coefficients were therefore measured in depthaveraged conditions. Consequently, all the materials making up an aquifer have been brought together to define a "mean material" which could be described as gravely sands (or sandy gravels), referring to the marked dominance of gravels and sands in Pleistocene and Holocene aquifer units.

Values of the storage coefficient and effective porosity are determined, following the same assumption, for all the Holocene aquifers on the one hand, and the Pleistocene aquifer on the other hand. The silty clayey layer found within the Pleistocene deposits, at an altitude close to $-50 \mathrm{~m}$ (Jusseret et al., as previously given, "The stratigraphical architecture of the Quaternary deposits as support for hydrogeological modelling of the central area of Hanoi (Vietnam)", unpublished report, 2008) is also included in this "mean material", so that the Pleistocene aquifer is considered as a unique gravely sandy layer. This hypothesis could also be supported by the discontinuous character of the " $-50 \mathrm{~m}$ " silty clayey layer.

It is however necessary to model explicitly the basal Holocene less permeable unit, because of the different piezometric heads observed in the Pleistocene and in the Holocene aquifers (when this layer is observed). Figure 6, adapted from Jusseret et al. (Jusseret et al., as previously given, "The stratigraphical architecture of the Quaternary deposits as support for hydrogeological modelling of the central area of Hanoi (Vietnam)", unpublished report, 2008), represents, for example, one of the cross-sections showing the nature and spatial distribution of the sedimentary units explicitly included in the hydrogeological model. The corresponding cross-section is located in Fig. 7 (number 2). As this model aims to simulate groundwater flow at the regional scale, the possible anisotropy of the parameters is neglected. Thu and Fredlund (2000) have however demonstrated the simplistic character of this assumption when considering land subsidence processes.

On the basis of hydraulic conductivity $(K)$ values from pumping tests (Table 1; Fig. 8) interpreted in depthaveraged conditions, an equivalent hydraulic conductivity value of about $1 \mathrm{E}-04 \mathrm{~m} / \mathrm{s}$ is found for the gravely sandy Holocene deposits. This latter value thus corresponds to an equivalent homogeneous material chosen for the Holocene channel gravels and sands.

Concerning the storage coefficient $(S)$, data gathered (Table 2) provide an equivalent storage coefficient of the

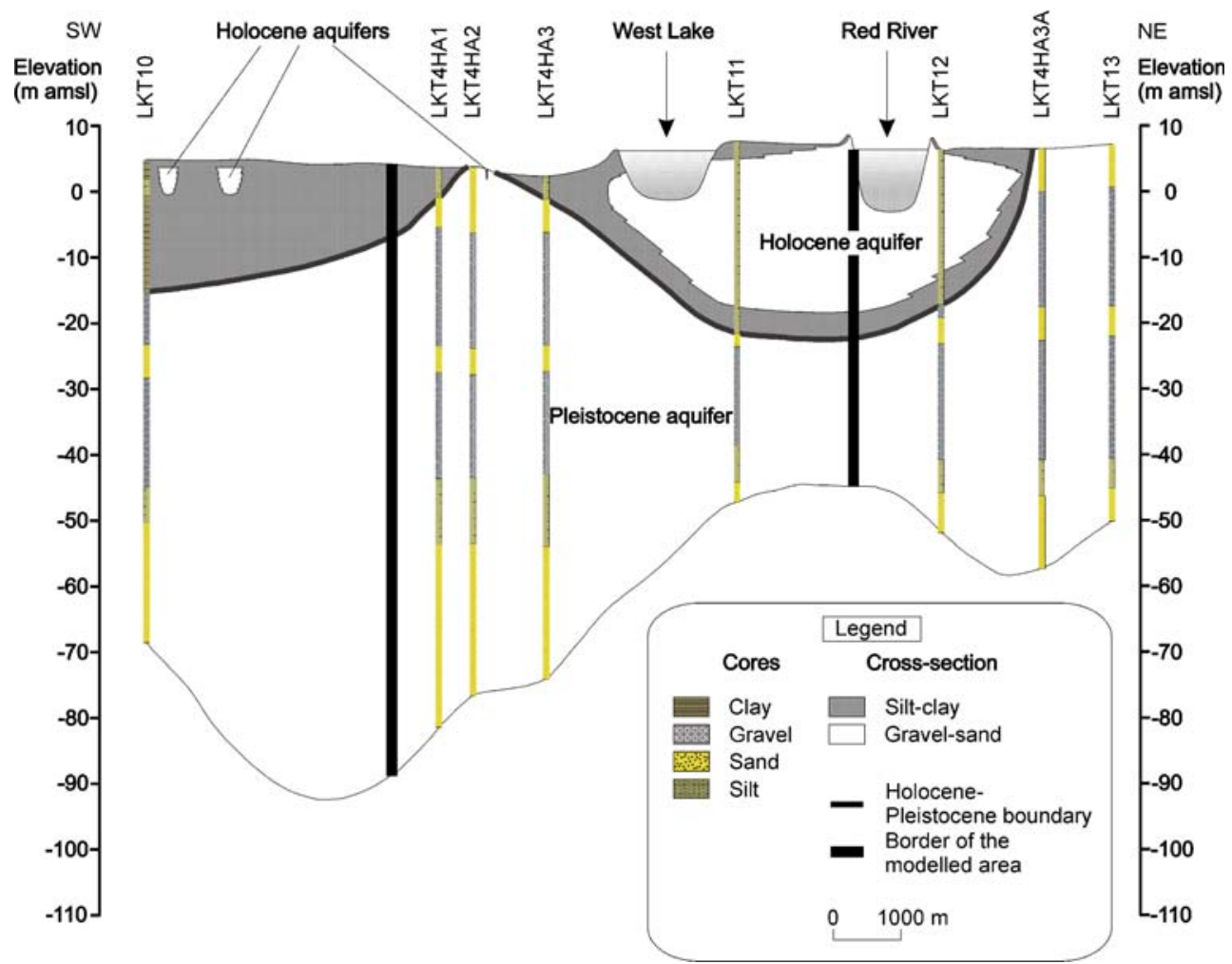

Fig. 6 Illustration of the spatial distribution of the sedimentary and hydrogeological units included in the groundwater flow model (crosssection number 2, see Fig. 7 for location) 


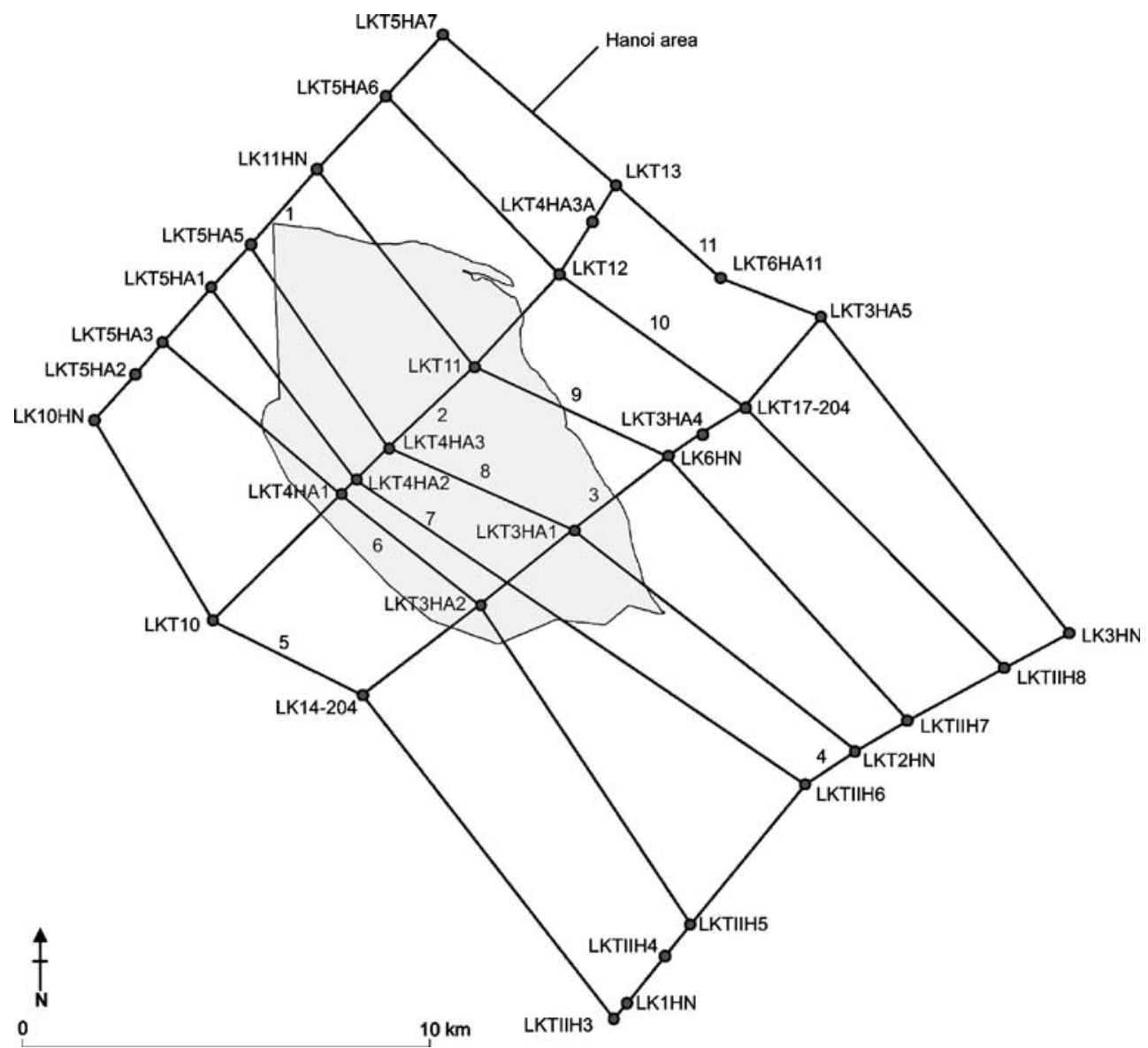

Fig. 7 Location of cross-sections (numbers 1-11) in the Hanoi area (modelled area is light grey). Section 2 is shown in Fig. 6

Holocene aquifers in the order of magnitude of 1 E-02 to 1 E-01 (-) showing that these aquifers are or become unconfined when and where pumping tests were performed. In deeper zones (permanently saturated), the definition of the storativity is closer to that defined for a confined aquifer. Smaller storativity values have therefore to be defined. If a value of $1 \mathrm{E}-08 \mathrm{~Pa}^{-1}$ is given for the volumic compressibility $(\alpha)$, a storage coefficient in the order of magnitude of $1 \mathrm{E}-04$ to $1 \mathrm{E}-03$ (-) is obtained. The latter values are acceptable for a nearly incompressible aquifer whose thickness varies from a few to tens of meters. A similar procedure is adopted for the Pleistocene aquifer parameters (Table 3, Fig. 8). An averaged equivalent value of $K$ is found close to that obtained for the Holocene units, i.e. order of magnitude of $K$ around 1 E-04 to $1 \mathrm{E}-03 \mathrm{~m} / \mathrm{s}$.

The value of the storage coefficient defined for the Pleistocene aquifer covered by a Holocene sedimentary layer is between $1 \mathrm{E}-05$ and $1 \mathrm{E}-01$ (-) (Table 4). The calibration of the transient-state model on measured piezometric head time series will provide additional information. The variability from $1 \mathrm{E}-05$ to $1 \mathrm{E}-01$ is certainly a consequence of the semi-confined character of the Pleistocene aquifer covered by Holocene deposits. Table 5 (outcropping Pleistocene aquifer) shows a set of values which could be related to the effective porosity $\left(n_{\mathrm{e}}\right)$ values of sandy gravely sediments. In outcrop areas, where the aquifer is unconfined, a storativity value in the order of magnitude of $1 \mathrm{E}-02$ to $1 \mathrm{E}-01$ (-) is thus admitted in the zone of intermittent saturation. At greater depths, where the intermittent saturation is not observed, the storage coefficient is, as for Holocene aquifers, characterized by values between 1 E-05 and 1 E-03 (-).

For the silty clayey layers, a conventional range of values have been chosen. Hydraulic conductivity values on the one hand have been defined between $1 \mathrm{E}-05$ and 1 E-09 $\mathrm{m} / \mathrm{s}$, depending on the proportion of coarse elements (silts) compared to clays (Fetter 2001). A storage coefficient corresponding to the value adopted for the confined aquifer multiplied by 5 has, on the other hand, been chosen. This choice takes into account the important total porosity (up to $50 \%$ ) and volumic compressibility $(\alpha)$ of these materials. Two main recharge sources of the aquifers can be distinguished: rainfall and the Red River. The unknown rates of recharge through surface-water bodies (smaller rivers, lakes) are here conceptually included in the effective rainfall term. This term is approximated by subtracting the potential evapotranspiration from the raw rainfall data at disposal.

In Hanoi, the thickness of the unsaturated zone generally reaches a few meters, possibly more where a Holocene aquifer is not recorded. Consequently, it is 


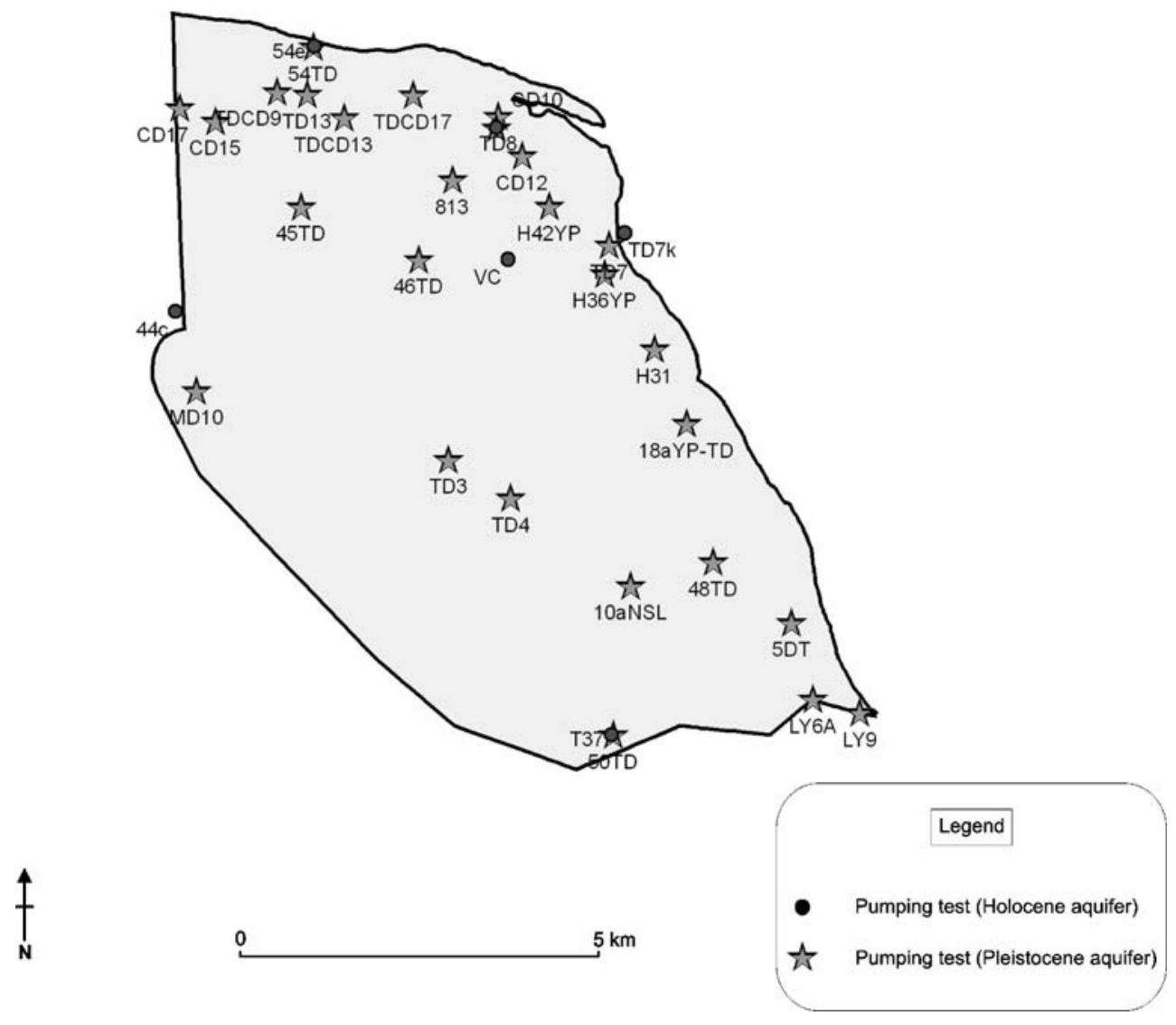

Fig. 8 Pumping tests carried out inside and close to the modelled area

acceptable to suppose that the recharge flow rates related to rainfall (between April and September, i.e. the rainy season) undergo an annual "smoothing" that is accentuated by the presence of many small surface-water bodies.

Three potential scenarios, principally differing in the spatial distribution of the infiltration rates, are tested in the model. The first scenario considers no infiltration related to rainfall. This scenario, undoubtedly far from the reality, will force the model to exaggerate the importance of the recharge from the Red River. The second scenario simulates infiltration only where superficial Holocene and Pleistocene gravely sandy deposits are occurring, and in West Lake and White Silk Lake (Fig. 9). The hydraulic conductivity values related to the lacustrine sediments are considered as equal to those of the gravely sandy sediments. With this scenario, infiltration through the superficial silty clayey deposits is conceptually chosen to be zero, with hydraulic conductivity of the order of magnitude of $1 \mathrm{E}-09 \mathrm{~m} / \mathrm{s}$. The third and last infiltration scenario considers an infiltration distributed over the whole study area. In this scenario, the hydraulic conductivity value of the superficial silty clayey sediments is therefore chosen with a maximum value of 1 E- $05 \mathrm{~m} / \mathrm{s}$.

The groundwater recharge through the Red River is included in the boundary conditions of the model. Secondary rivers and lakes are represented as gravely sandy "windows", opened on Holocene aquifers and through which water from rainfall is infiltrating. The only (known) groundwater sink term in Hanoi is represented by the public and private pumping wells.

Nowadays, ten main pumping fields exist in Hanoi. Six of them are located in the modelled area: Cao Dinh, Long Yen, Mai Dich, Ngoc Ha, Ngo Si Lien and Yen Phu (Fig. 5). The shift from the 1990s to the 2000s would have been accompanied by a linear rise of the pumping rates, from 430,000 to $473,780 \mathrm{~m}^{3}$ /day (RIGMR 2006; database); these rates are moreover exclusively related to the Pleistocene aquifer. Available pumping rate data (Table 6) are referring to an unknown period, but definitely after 2000 (V.T. Tam, MONRE, personal communication, 2006). Because of this uncertainty, the pumping rate data given in Table 6 are hypothetically reported to the month of December 2004. For the same reason, the linear rise previously mentioned (from 430,000 to $473,780 \mathrm{~m}^{3} /$ day) is considered as representative of the modelled period (January 1995-December 2004). Monthly pumping rates from January 1995 onwards are calculated on the basis of this ratio and of the pumping rates of December 2004 (Table 6). Within each pumping field, the total pumping rate is equally shared out among the wells. The depths of the well screens are only known for the nine wells belonging to one particular pumping field (Khuong Trung, located to the south and outside of the modelled area): the mean depth of the bottom of the screen is around $-50 \mathrm{~m}$, while the top of the screen is around $-30 \mathrm{~m}$. These values are adopted for each well in the modelled area. 


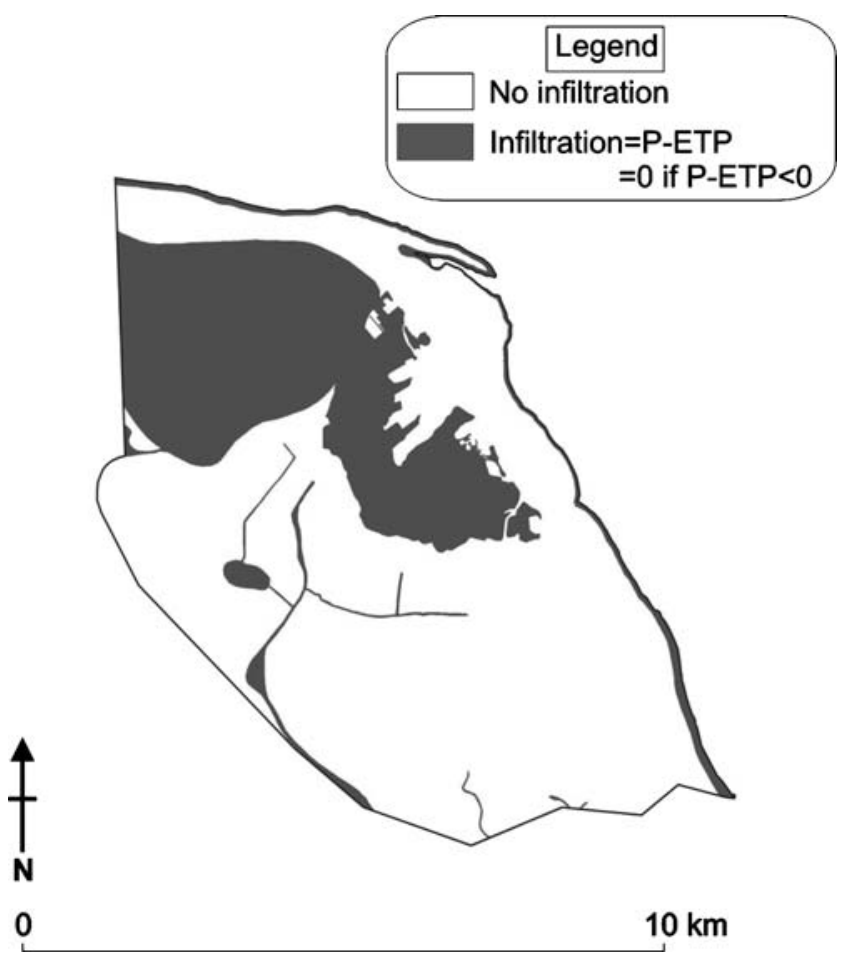

Fig. 9 Map of the modelled area, illustrating the spatial distribution of the infiltration related to precipitation, as defined in the second conceptual model of recharge ( $P$ precipitation, $P E T$ potential evapotranspiration)

The database of RIGMR (2006) also identifies private pumping wells inside the urban zone of Hanoi, which broadly corresponds to the study area. These private withdrawals are, in Hanoi, an important sink term as they represent more than one third of the rates officially pumped-close to $120,000 \mathrm{~m}^{3} /$ day according to the database of RIGMR (2006). The great number of private pumping wells south of the Red River, as well as the small values of the individual pumping rates leads to conceptualize this solicitation as a negative flux uniformly spread over the modelled area. The evolution of this sink term between 1995 and 2004 is defined following the same process as that adopted for public pumping wells (linear variation). The pumping rate for January 1995 has been chosen as null, a hypothesis which could be acceptable if one supposes that the appearance and growth of the private companies' water needs have followed the recent economic development of Hanoi. December 2004 saw a pumping rate of $120,000 \mathrm{~m}^{3} / \mathrm{s}$, following the same logic as that adopted for the evolution of the public pumping rates.

The hypotheses concerning the ways of defining the Red River boundary condition and the recharge by precipitation have been combined to obtain the two groups of three conceptual models, detailed below.

1. Models with a Red River boundary condition imposed by the measurements at three stations (group 1): without infiltration (model 1.1); with infiltration through superficial gravely sandy deposits only, with minimized hydraulic conductivity of the silty clayey deposits belonging to the first layer (model 1.2); with infiltration through the whole surface of the model, with maximized hydraulic conductivity of the silty clayey deposits belonging to the first layer (model 1.3) 2. Models with a Red River boundary condition imposed by the measurements at two stations (group 2): without infiltration (model 2.1); with infiltration through superficial gravely sandy deposits only, with minimized hydraulic conductivity of the silty clayey deposits belonging to the first layer (model 2.2); with infiltration through the whole surface of the model, with maximized hydraulic conductivity of the silty clayey deposits belonging to the first layer (model 2.3).

\section{Data input}

Using the MODFLOW 2000 calculation code, the constructed mesh includes 102,405 cells equally spread over five layers. Cell dimensions are horizontally fixed to $55 \mathrm{~m}$ (west-east axis) and $57 \mathrm{~m}$ (north-south axis), without any refinement areas. This choice results from the uncertainty related to the pumping rates, which does not justify the need for obtaining more accurate results in some specific stressed areas. Besides the upper and lower boundaries of the mesh, built on the basis of core data, the elevation of the five layers of cells are as follows: $2 \mathrm{~m}$ amsl (base of layer 1, top of layer 2), $-8 \mathrm{~m}$ amsl (base of layer 2, top of layer 3), $-18 \mathrm{~m}$ amsl (base of layer 3, top of layer 4), $-23 \mathrm{~m}$ amsl (base of layer 4, top of layer 5).

Figure 10 illustrates the spatial distribution of the parameters related to the five layers of the mesh. Fig. 11 shows an example of the application of this distribution to one of the cross-sections, located on Fig. 7 (cross-section number 2). The groundwater level measurements as given by the P37, P36, P39, P38, Q64, P12, P8, Q63, P9 and P21 wells are exploited to define boundary conditions of the model. The data related to the observation wells located in the modelled zone (11 for the Pleistocene aquifer, 5 for the Holocene aquifers, see Fig. 3) are used for the calibration of the model.

\section{Results}

The six conceptual models presented above were first successively tested in order to define the most adapted hypotheses related to the modelled area and considered period (1995-2004). The objective function $(F)$ here exploited corresponds to a RMS (root mean square) error, calculated on the basis of observed (measured) and calculated piezometric heads. A trial-and-error procedure was chosen for minimizing $F$.

Because of the construction of six models, hydraulic conductivity represents the only parameter likely to be modified by the manual calibration. $K$ is not allowed to vary within a same aquifer unit, i.e. Holocene or Pleistocene. Where silty clayey sediments are concerned, 


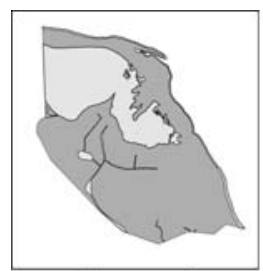

Layer 1

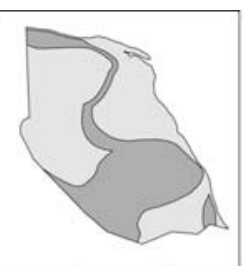

Layer 2

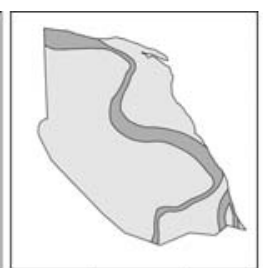

Layer 3

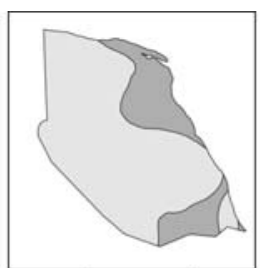

Layer 4

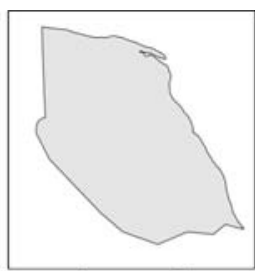

Layer 5
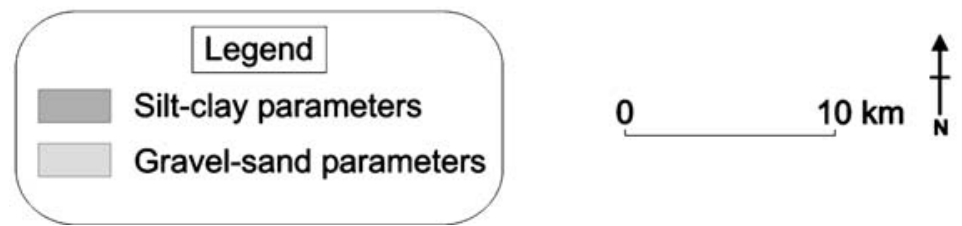

Fig. 10 Spatial distribution of the hydrogeological parameters in the five layers of the constructed model

$K$ receives an identical value in a given layer of the mesh but can vary from one layer to another.

\section{Steady-state conditions}

The calibrated and validated values of $K$, obtained in steady-state conditions and shared by the six conceptual models, are summarized in Table 7. The calibration process was carried out on the basis of the data of January 1995, while validation was envisaged on the basis of the data related to the months of July 1995, January 2000, July 2000, January 2004 and July 2004. These steadystate calibration and validation processes led to the selection of the most efficient model (model 1.2) for a) Cross-section

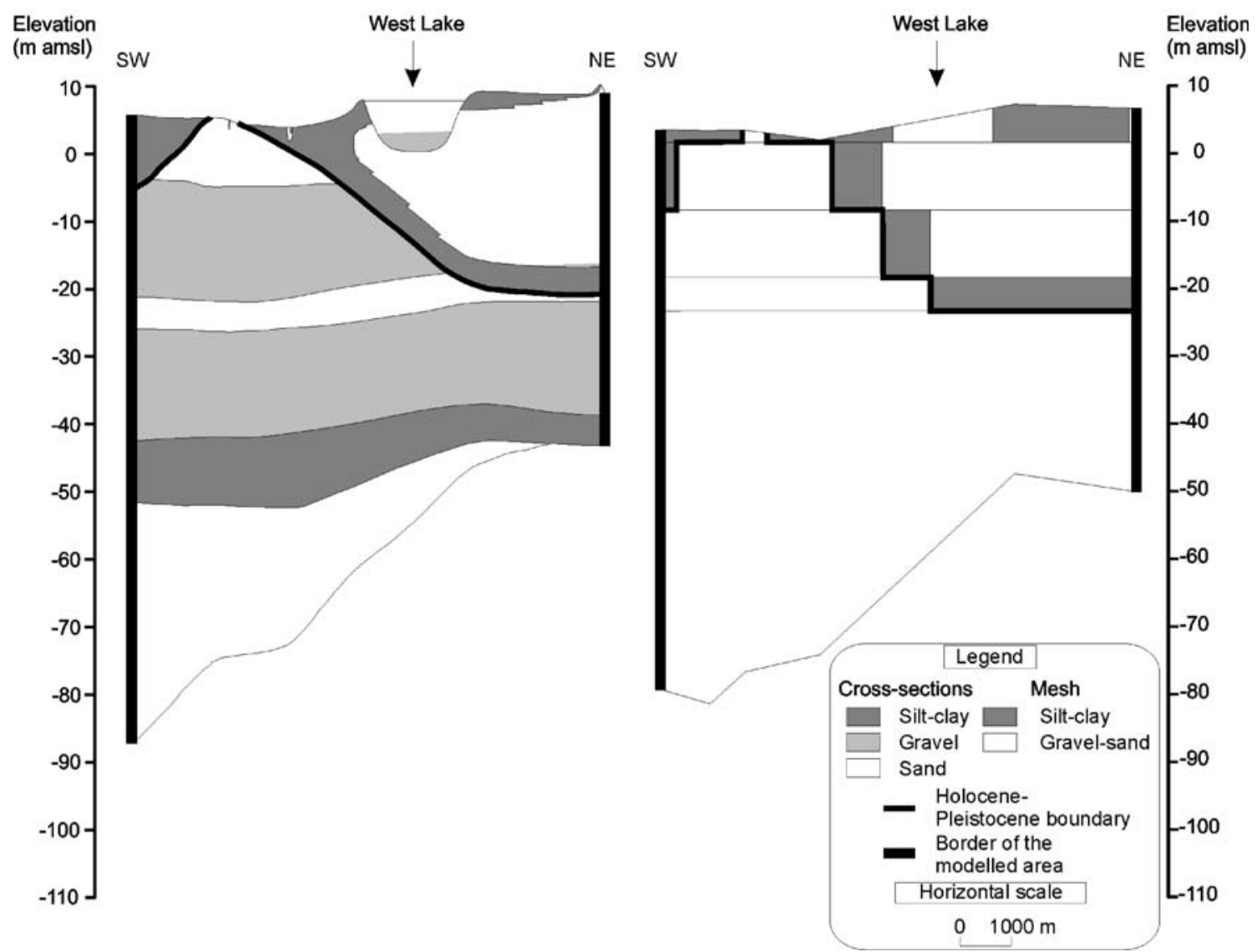

Fig. 11 a Cross-section number 2 in the modelled domain. b Spatial discretization of cross-section number 2 in the modelled domain. See Fig. 7 for location 
Table 7 Calibrated and validated values of $K$ (steady-state conditions)

\begin{tabular}{ll}
\hline Material & $K(\mathrm{~m} / \mathrm{s})$ \\
\hline Gravels-sands (Holocene) & 5 E-04 \\
Gravels-sands (Pleistocene) & 9 E-04 \\
Silts-clays (layer 2) & 4 E-08 \\
Silts-clays (layers 3 and 4) & 1.9 E-08 \\
\hline
\end{tabular}

simulating groundwater flows during the selected periods, inside the $63-\mathrm{km}^{2}$ study area. As a consequence, it could also be determined that (1) the Red River boundary was more accurately defined by using the measures given by three stations rather than two and, more importantly, that (2) among the given hypotheses, the infiltration process could be best conceptualized as occurring through superficial gravely sandy deposits with a minimized hydraulic conductivity $(1 \mathrm{E}-09 \mathrm{~m} / \mathrm{s})$ of the silty clayey deposits belonging to the first layer.

The application field of these conclusions, of course, does not go beyond the boundaries of the modelled area. These final observations however have good chances to be applicable to periods different to those used for the calibration and validation processes. This statement can be justified by the fact that the proposed simulation is based on physical (mathematical description of the groundwater flows in saturated conditions) and sedimentological principles which guarantee the reliability of the model used for predictive purposes.

The sensitivity analysis carried out in steady-state conditions, on the basis of model 1.2 running with the data related to January 1995, led to the following conclusions (Figs. 12, 13 and 14):

- The calculated results for the Pleistocene aquifer are not very sensitive to an increase of $\mathrm{K}$.

- A variation of $K$ of the silts and clays separating the Pleistocene and Holocene aquifers strongly modifies the calculated results for the Holocene aquifers.

- The model is generally more sensitive to the variation of the parameters when comparing the results calculated for the Holocene aquifers to those calculated for the Pleistocene aquifer.

- The RMS errors seem to constrain $K_{\text {silts-clays }}$ to an order of magnitude of $1 \mathrm{E}-08 \mathrm{~m} / \mathrm{s}$ and $K_{\text {gravels-sands }}$ (regardless which aquifer unit) to a value superior or equal to $1 \mathrm{E}-04 \mathrm{~m} / \mathrm{s}$ (because of the sharp rise of the RMS error when considering lower values). The latter parameter can however be augmented by three orders of magnitude without significantly modifying the quality of the calculated results.

The sensitivity of the model when considering the Holocene aquifers has probably to be related to the spatial distribution of these units. The latter is indeed more constraining than that of the Pleistocene aquifer, forming a continuous unit, not laterally interrupted by less permeable deposits. Moreover, the calibrated set of hydraulic
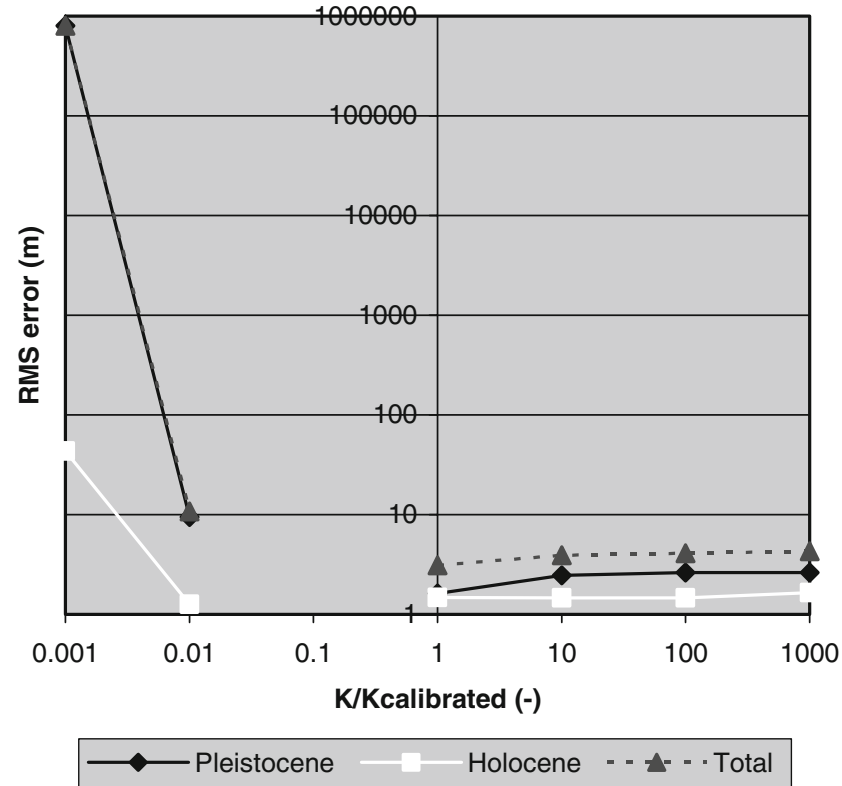

Fig. 12 RMS errors calculated as a function of the variation of $K_{\text {gravels-sands }}$ of the Pleistocene aquifer

conductivities does not always correspond to the minimal error calculated by the model (Fig. 14). This observation can be justified by the fact that the choice of the parameters has been made on the basis of the results calculated for six periods (validation process), while the sensitivity analysis has only been carried out on the basis of the January 1995 data. Concerning Fig. 12, the absence of value for a $K / K_{\text {calibrated of }} 0.1$ is explained by a calculated error too high for being represented.

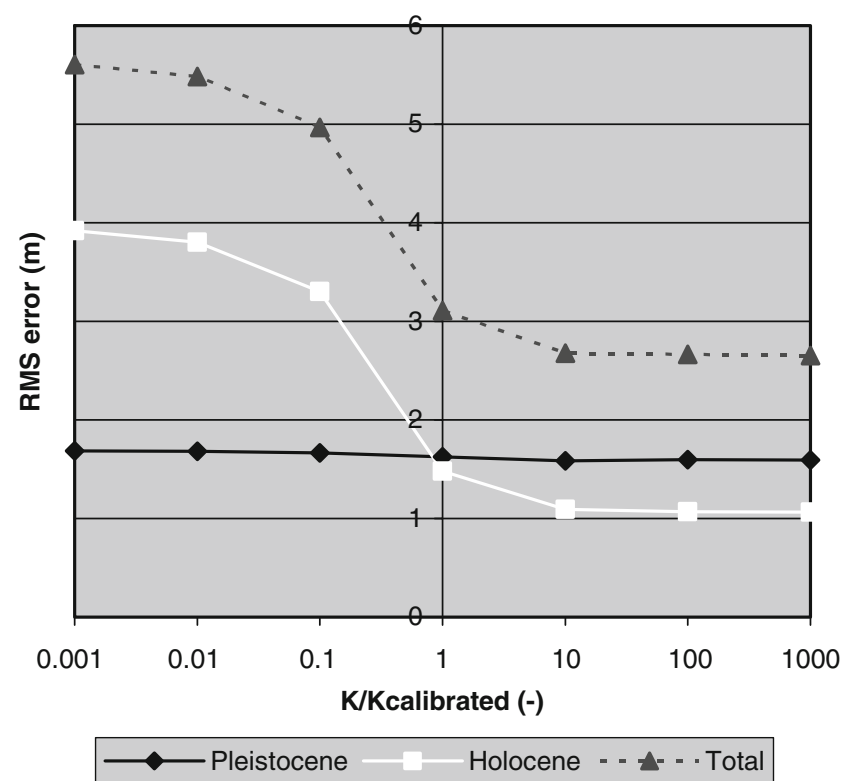

Fig. 13 RMS errors calculated as a function of the variation of $K_{\text {gravels-sands }}$ of the Holocene aquifers 


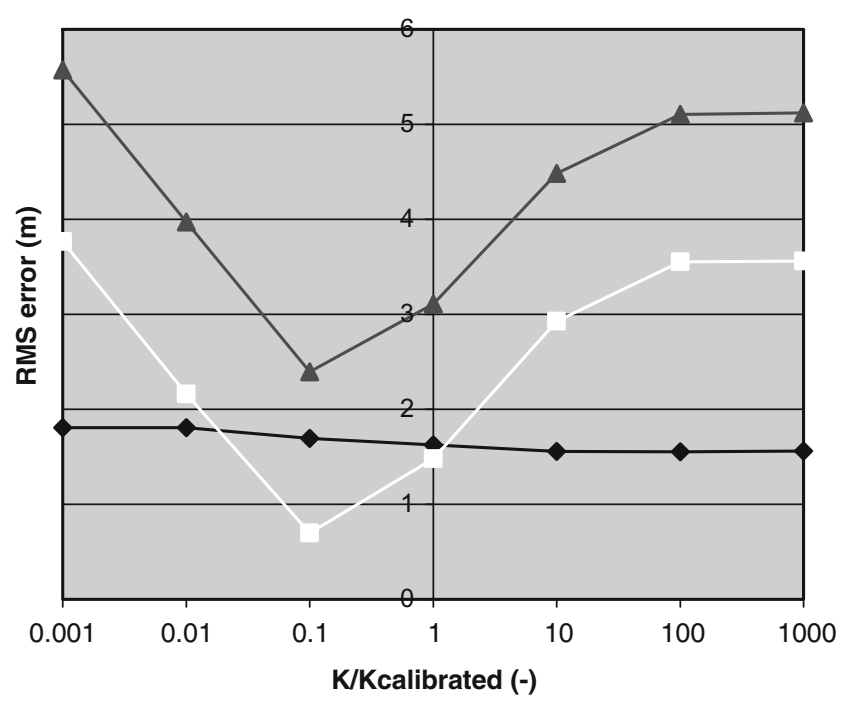

Pleistocene Holocene - - - - Total

Fig. 14 RMS errors calculated as a function of the variation of $K_{\text {silts-clays }}$ of the layers $2-4$

\section{Transient-state conditions}

The specific storage $\left(S_{\mathrm{s}}\right)$ and effective porosity $\left(n_{\mathrm{e}}\right)$ are the only parameters which have been modified in comparison with the calibration and validation processes in steady- state conditions. The initial conditions defined before starting the calibration in transient-state conditions are those calculated by model 1.2, running in steady-state conditions with the January 1995 data set. The piezometric maps calculated for the Pleistocene and Holocene aquifers and used as initial conditions are presented on Figs. 15, 16 and 17 (layer 1 is the uppermost). Light grey areas indicate calculated piezometric heads higher than the topographic surface, while dark grey zones indicate dry (inactive) cells. Note on these three figures, the pumpinginduced drawdown cone related to the Mai Dich and Ngoc Ha fields (Fig. 5), inducing the drainage of the cells above it and belonging to the first and second layers. As only the active cells are considered by the model when calculating further piezometry, these cells are not reactivated during later time steps. Considering the hydrogeological context encountered in Hanoi, with measured piezometric heads undergoing a nearly continuous lowering since 1995, this constraint does not create inconsistency. The modelling of the multi-annual trends can therefore be carried out starting from January 1995, which represents a "maximum" during the simulated period.

The calibration in transient-state conditions has been carried out on the basis of results comparison for the month of December in 1996, 1997, 1998, 1999, 2000, 2001, 2002, 2003 and 2004. Changing stresses and
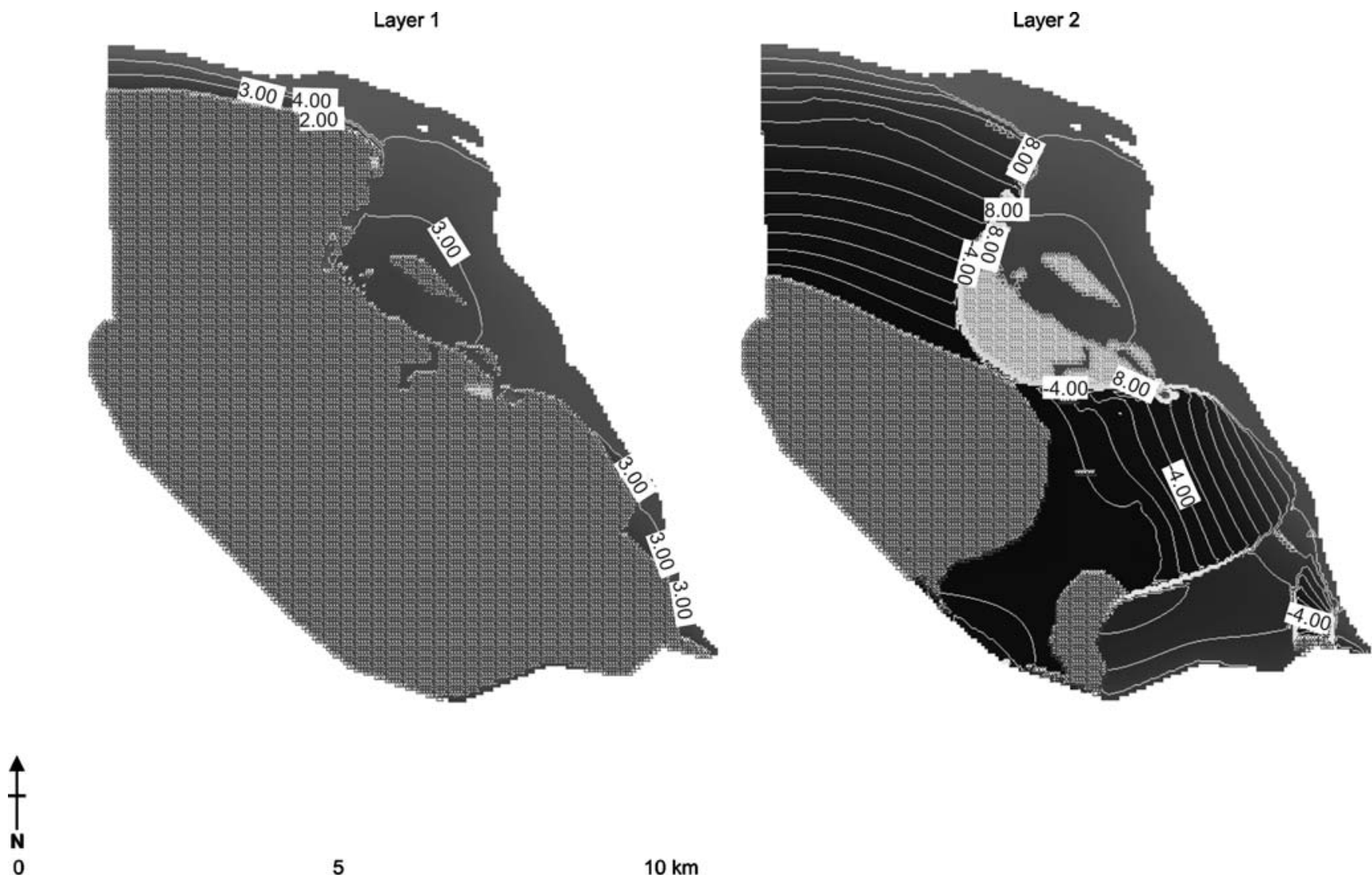
$10 \mathrm{~km}$

Fig. 15 Piezometric head maps calculated in steady-state conditions (model 1.2) with the data related to January 1995 (layers 1 and 2 ). Water levels are given in metres relative to $\mathrm{msl}$ 

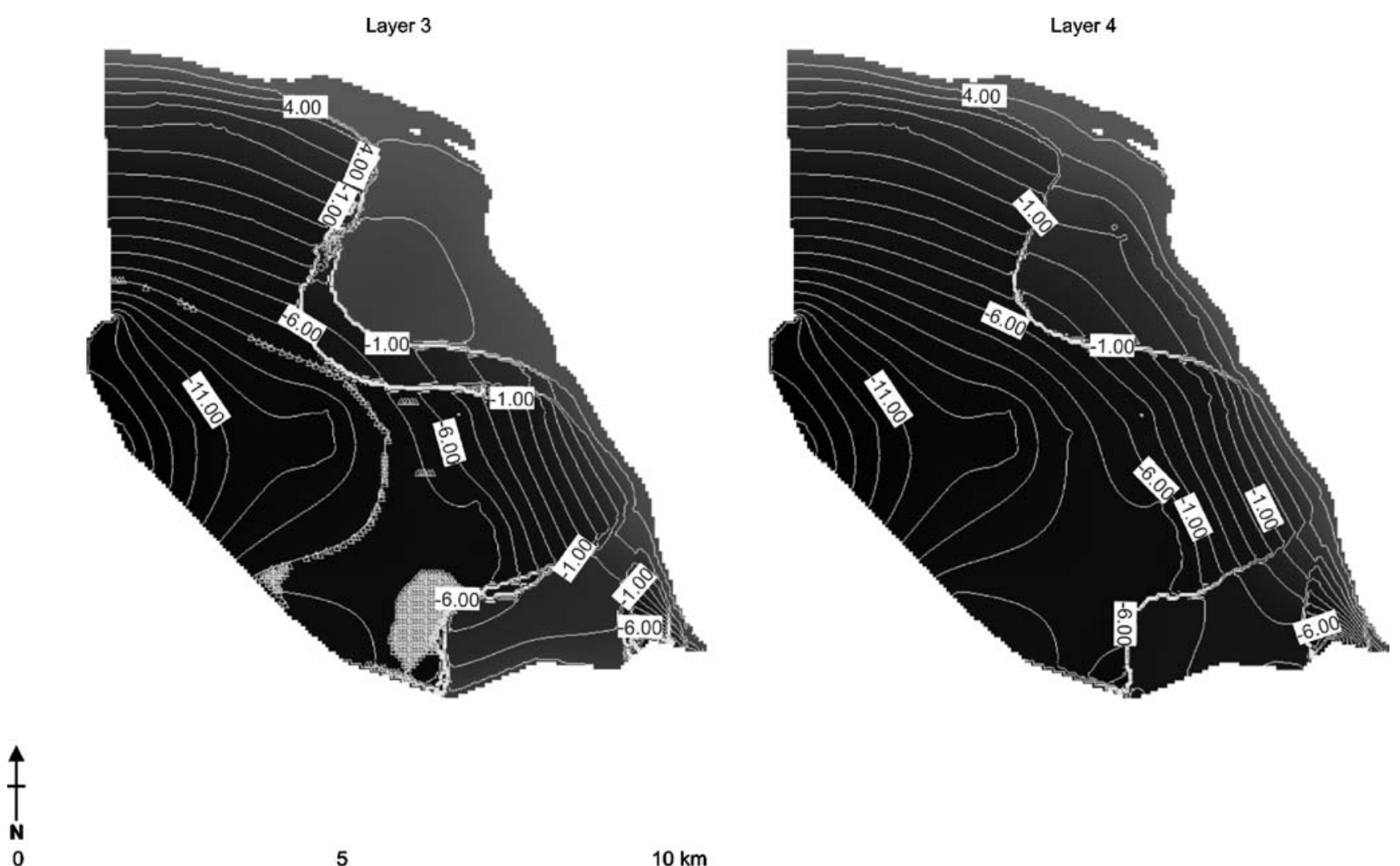

5

$10 \mathrm{~km}$

Fig. 16 Piezometric head maps calculated in steady-state conditions (model 1.2) with the data related to January 1995 (layers 3 and 4 ). Water levels are given in metres relative to $\mathrm{msl}$

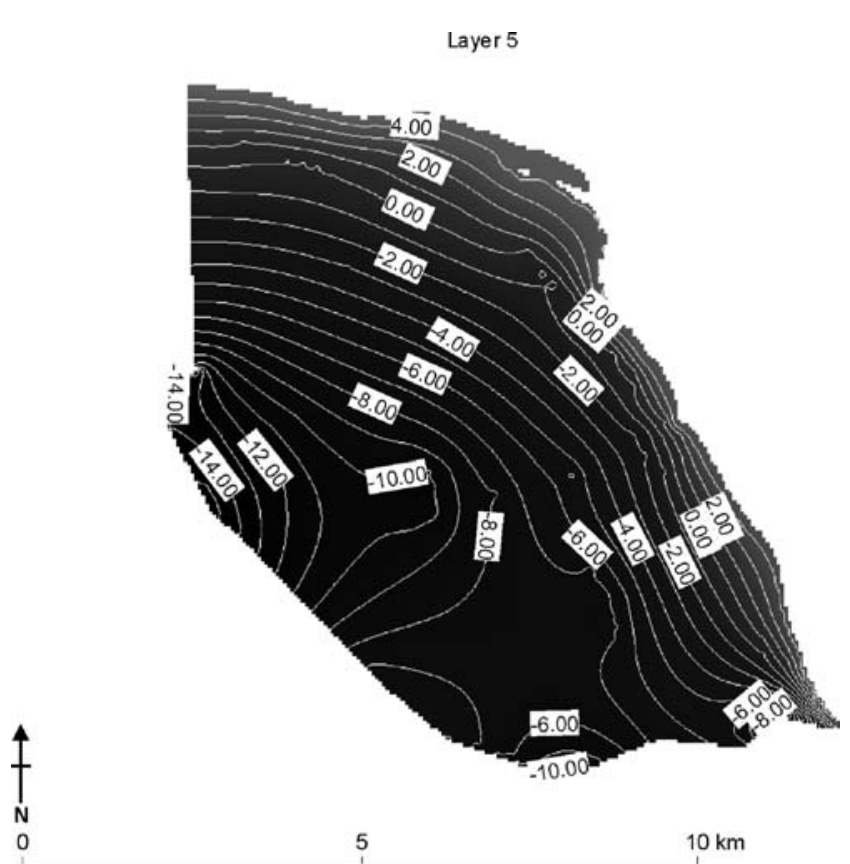

Fig. 17 Piezometric head map calculated in steady-state conditions (model 1.2) with the data related to January 1995 (layer 5, Pleistocene aquifer). Water levels are given in metres msl boundary conditions are taken into account in the model. The calibrated values of the specific storage $\left(S_{\mathrm{s}}\right)$ and effective porosity $\left(n_{\mathrm{e}}\right)$ are presented in Table 8 . Figure 18 illustrates a selection (December of 1995, 2000 and 2004) of scatter plots built on the basis of calculated versus measured piezometric heads at the end of each year. Considering the conceptual hypotheses adopted, the calculated results can be considered as very satisfactory: the scatter points follow a clear linear trend and the difference between calculated and measured values is less than one meter at several observation wells. Comparisons between the evolutions of calculated and measured piezometric heads are illustrated on Fig. 19. Again, the piezometric trends are fairly well simulated (general decrease through time, up- and down-going evolution),

Table 8 Calibrated values of specific storage $\left(S_{\mathrm{s}}\right)$ and effective porosity $\left(n_{\mathrm{e}}\right)$ in transient-state conditions, for the period between January 1995 and December 2004

\begin{tabular}{lll}
\hline Material & $n_{\mathrm{e}}(-)$ & $S_{\mathrm{S}}\left(m^{-1}\right)$ \\
\hline Gravels-sands (Pleistocene-Holocene) & $3 \mathrm{E}-01$ & $2 \mathrm{E}-04$ \\
Silts clays & $1 \mathrm{E}-03$ & $3 \mathrm{E}-01$ \\
\hline
\end{tabular}




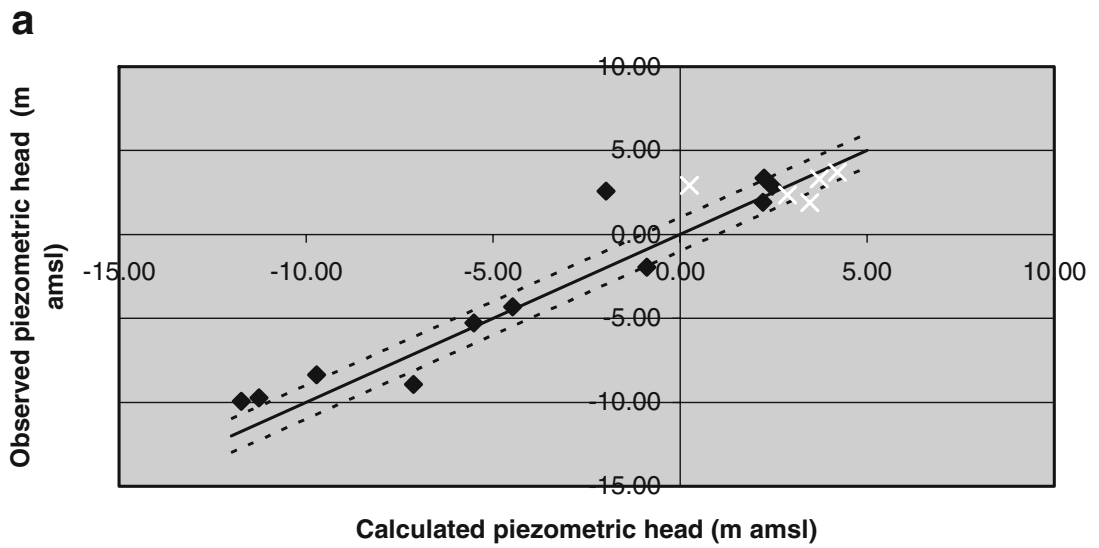

Pleistocene $\longrightarrow$ Hcalc=Hobs - - - Hcalc=Hobs $+/-1 \mathrm{~m} \quad$ Kolocene

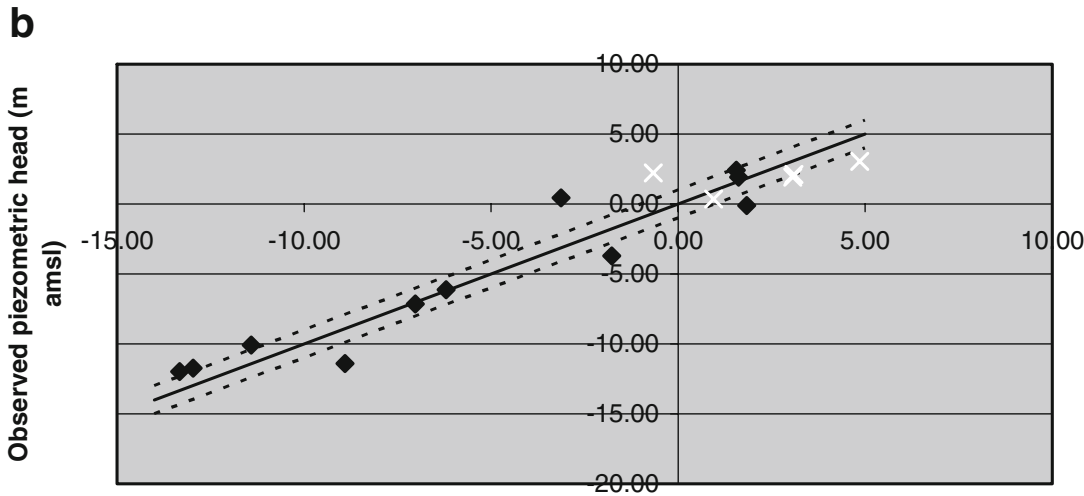

Calculated piezometric head (m amsl)

Pleistocene $\longrightarrow$ Hcalc=Hobs - - - Hcalc=Hobs $+/-1 \mathrm{~m} \times$ Holocene

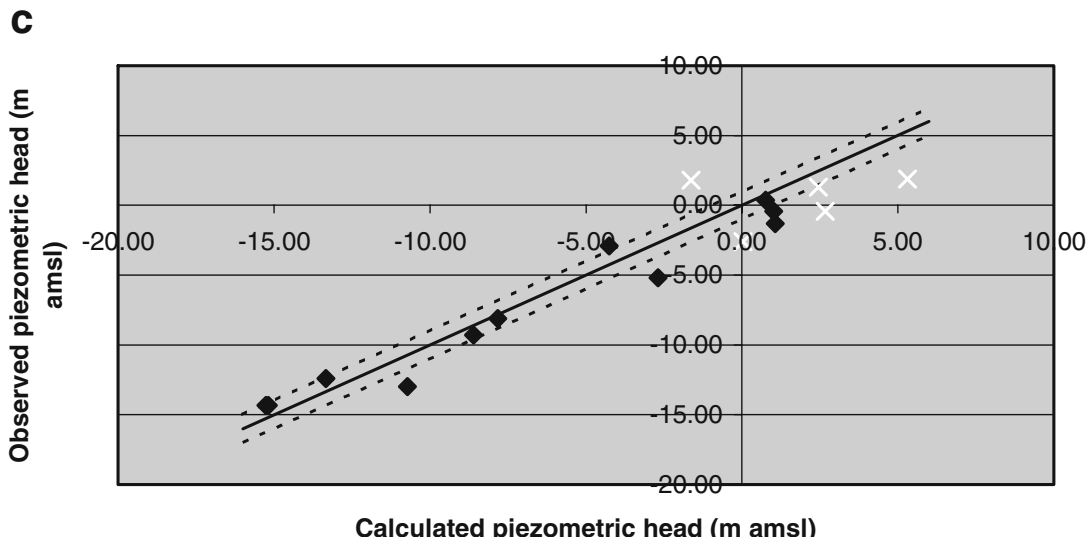

Calculated piezometric head (m amsl)

Pleistocene $\longrightarrow$ Hcalc=Hobs - - - Hcalc=Hobs $+/-1 \mathrm{~m} \times$ Holocene

Fig. 18 Scatter plots obtained after calibration in transient-state conditions (December of a 1995, b 2000, c 2004)

with the exception of the P47 (Holocene aquifer) and P17 (Pleistocene aquifer) observation wells. The former shows a trend not satisfactorily reproduced; the latter systematically furnishes calculated values several meters below the observed ones (up to $7 \mathrm{~m}$ for December 2001).
Validation was carried out by testing seasonal variations (Fig. 20). The calculated trends are again well reproduced, except for the variations of the Pleistocene groundwater at P17 and of the Holocene aquifer at P35. The RMS error calculated for the whole aquifer units 
P17 Holocene

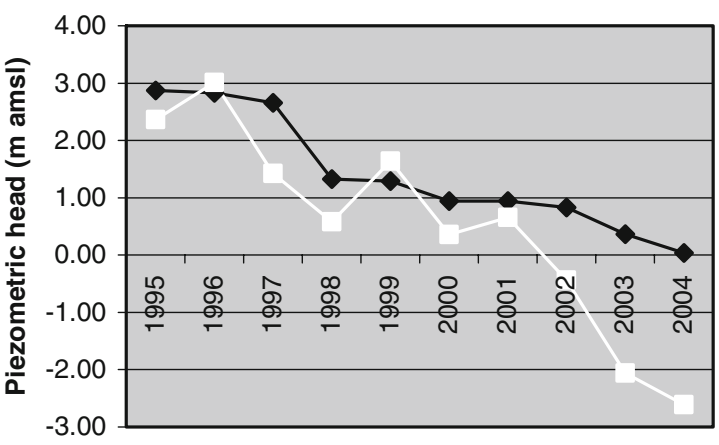

Calculated - Observed

P17 Pleistocene

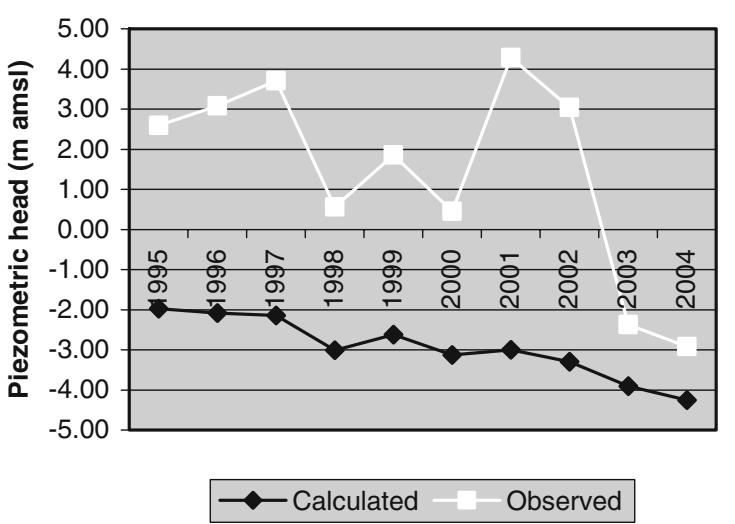

P35 Pleistocene

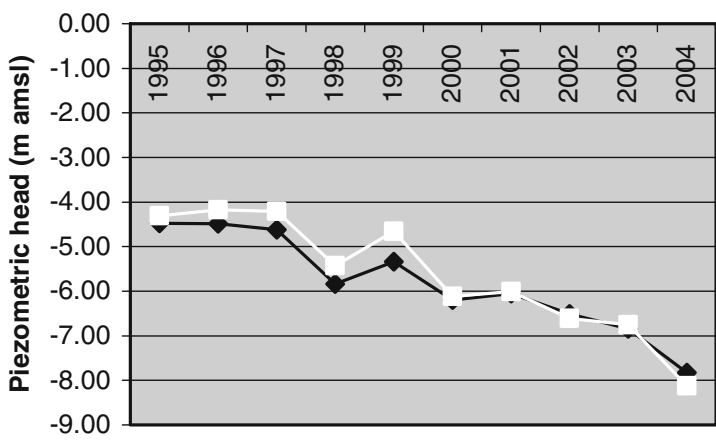

Calculated - Observed
P47 Holocene

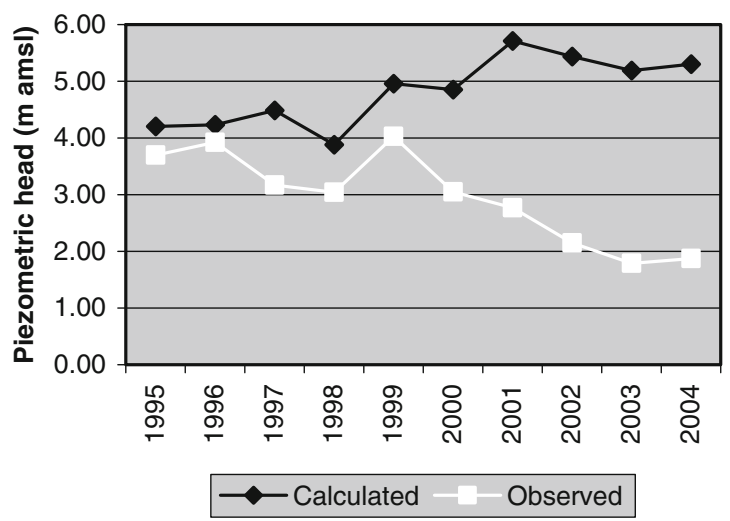

P47 Pleistocene

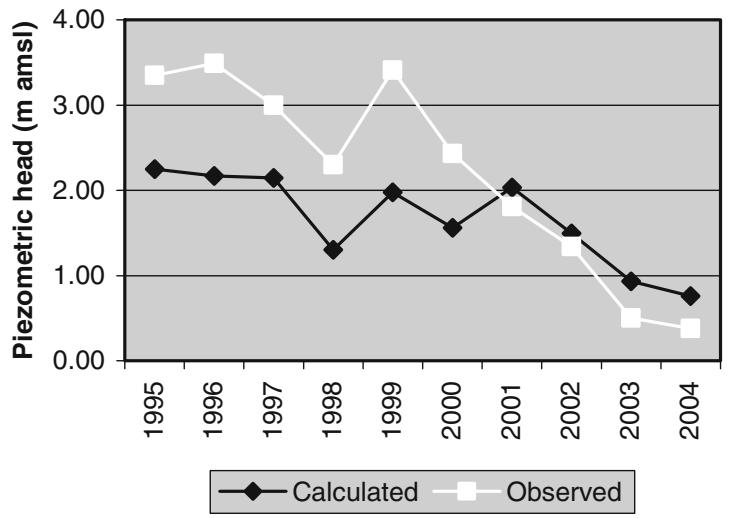

P43 Pleistocene

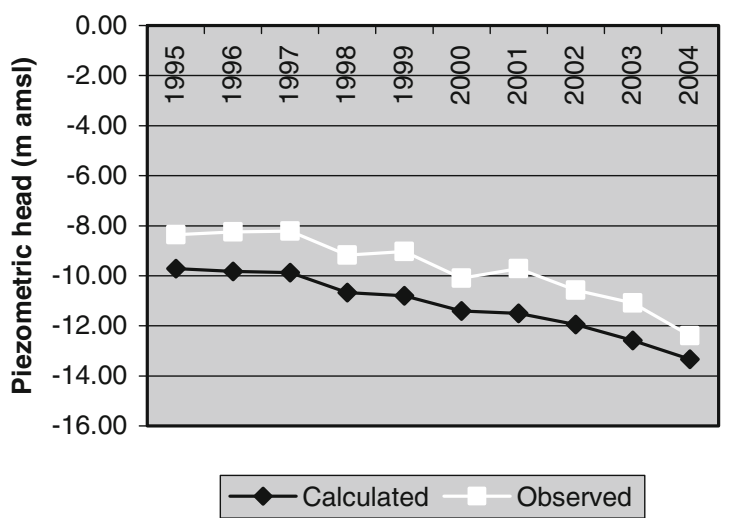

Fig. 19 Comparison between the calculated and observed piezometric heads at the $P 43, P 35, P 17$ and $P 47$ observation wells (transientstate conditions, annual time step marked out for December of each year)

(Holocene and Pleistocene), $1.6 \mathrm{~m}$, demonstrates the very satisfactory quality of the model, in spite of the strong conceptual choices made. The constructed model shows a very weak sensitivity to the variation of the specific storage and effective porosity of the encountered materials (decrease of the RMS error by $5 \mathrm{~cm}$ when multiplying the specific storage by 100). The constructed model hence is not authorized to constrain the orders of magnitude of the specific storage and effective porosity for the equivalent materials defined in the study area.

\section{Interpretation of the results}

The calibration and validation of the constructed groundwater flow model answers the initially asked questions.

According to the obtained values of the objective function, in steady- and transient-state conditions, the sedimentological model seems to be efficient to simulate the three-dimensional geometry of the layers and the heterogeneity influencing the three-dimensional groundwater flow in saturated conditions. The semi-annual piezometric variations observed between 1995 and 2004 


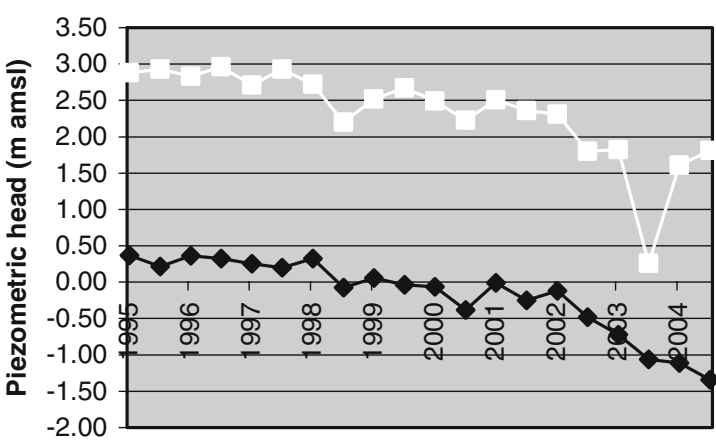

Calculated - Observed

P35 Pleistocene

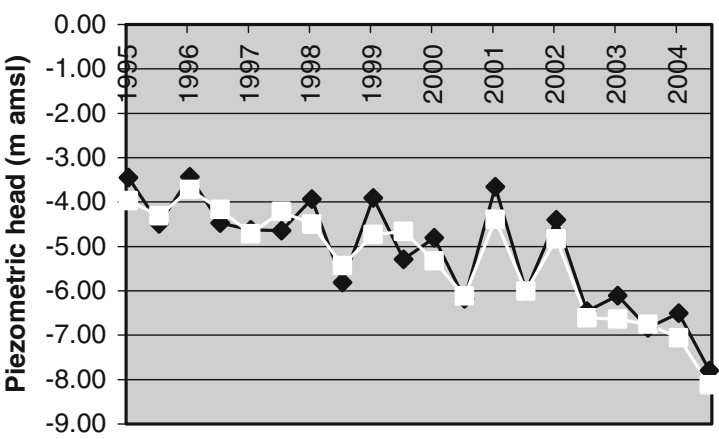

Calculated - Observed

P43 Pleistocene

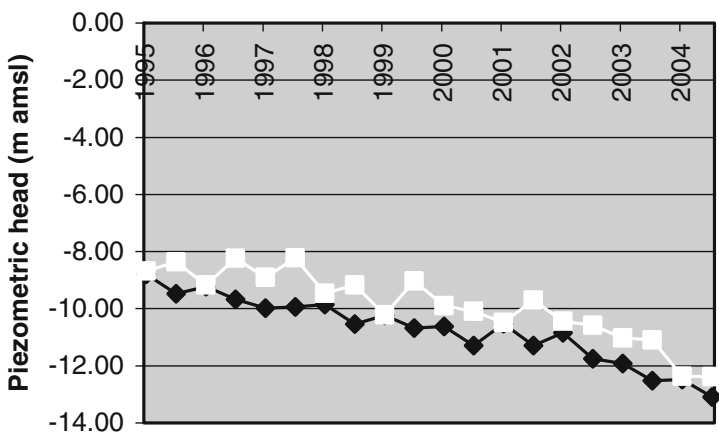

- Calculated - Observed

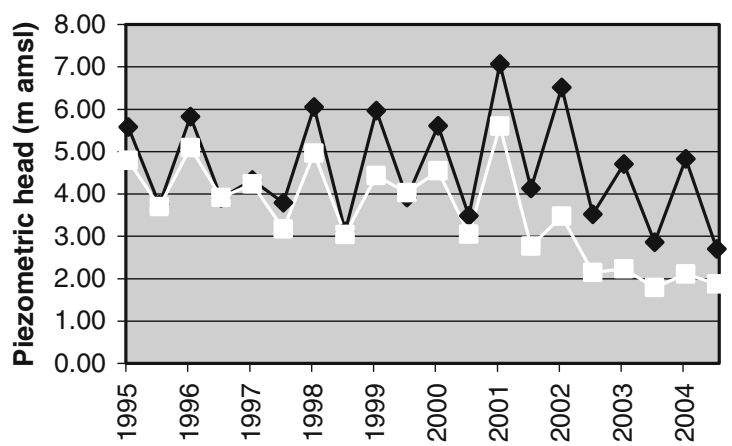

- Calculated - Observed

P17 Pleistocene

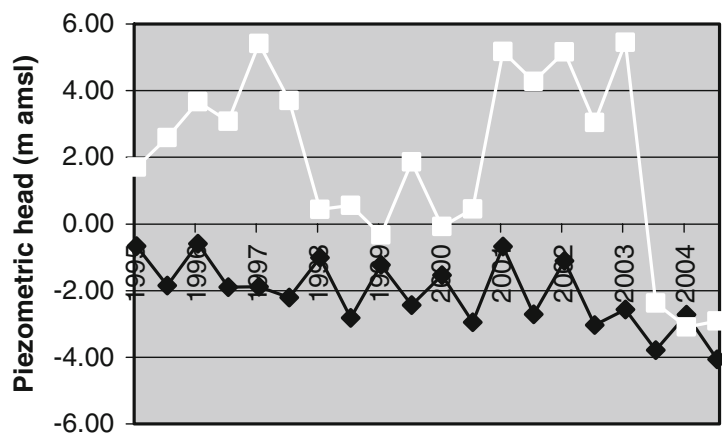

- Calculated - Observed

P58 Pleistocene

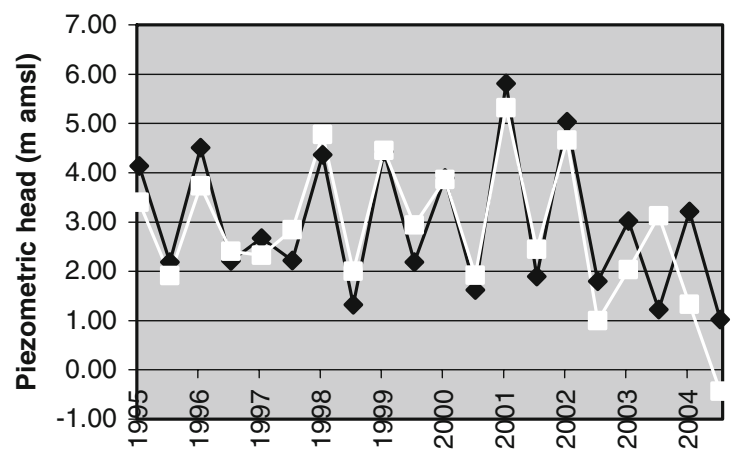

$\multimap$ Calculated - Observed

Fig. 20 Comparison between the calculated and observed piezometric heads at the $P 43, P 35, P 58, P 17$ and $P 47$ observation wells (transient-state conditions, semi-annual time step marked out for June and December of each year)

are also well simulated, with the exception of the P17 (Pleistocene aquifer) and P35 (Holocene aquifers) observation wells.

1. Following the conceptual hypothesis expressed through the Red River boundary condition with a prescribed piezometric head varying linearly between the three measuring stations, the flow rate entering the model through this boundary (January 1995, steady-state conditions) and calculated by MODLFOW is about
$4.78 \mathrm{~m}^{3} / \mathrm{s}$. This flow rate is very unequally shared out between the five modelled layers. In all, 93\% of this flux is indeed entering layer 5, exclusively representing the Pleistocene aquifer. The infiltration from rainfall is between $0.9 \mathrm{~m}^{3} / \mathrm{s}$ (recharge through Pleistocene outcrops, lakes and watercourses) and $3.03 \mathrm{~m}^{3} / \mathrm{s}$ (maximum infiltration, i.e. through the whole study area). The main recharge source of the groundwater in the modelled domain (in January 1995) is the Red River. Depending on the chosen conceptual model of re- 
charge, the relative importance of the recharge from the Red River as compared to recharge from the rainfall is varying. The calibration in steady-state conditions shows a rainfall infiltration rate in January 1995 closer to $0.9 \mathrm{~m}^{3} / \mathrm{s}$ than $3.03 \mathrm{~m}^{3} / \mathrm{s}$. Even with a maximum recharge by rainfall infiltration, the latter only represents $63 \%$ of recharge from the Red River.

2. The validation of the model in transient-state conditions with pumping conditions led to calculated piezometric maps related to the months of June (rainy season) and December (dry season) for the period 1995-2004. The regional groundwater flow trends are compared mostly within layer 5 (representing the biggest part of the modelled domain). As an example, Fig. 21 illustrates the piezometric maps calculated by MODFLOW for June and December 1999. The calculated groundwater levels are imposed (see boundary conditions) higher close to the Red River during the rainy than during the dry season. Around the Mai Dich pumping field, far from the Red River, the piezometry does not, on the other hand, strongly vary during the year. Regional groundwater flow trends are oriented orthogonally to the Red River boundary and converge to the pumping fields. The pumping drawdown cones
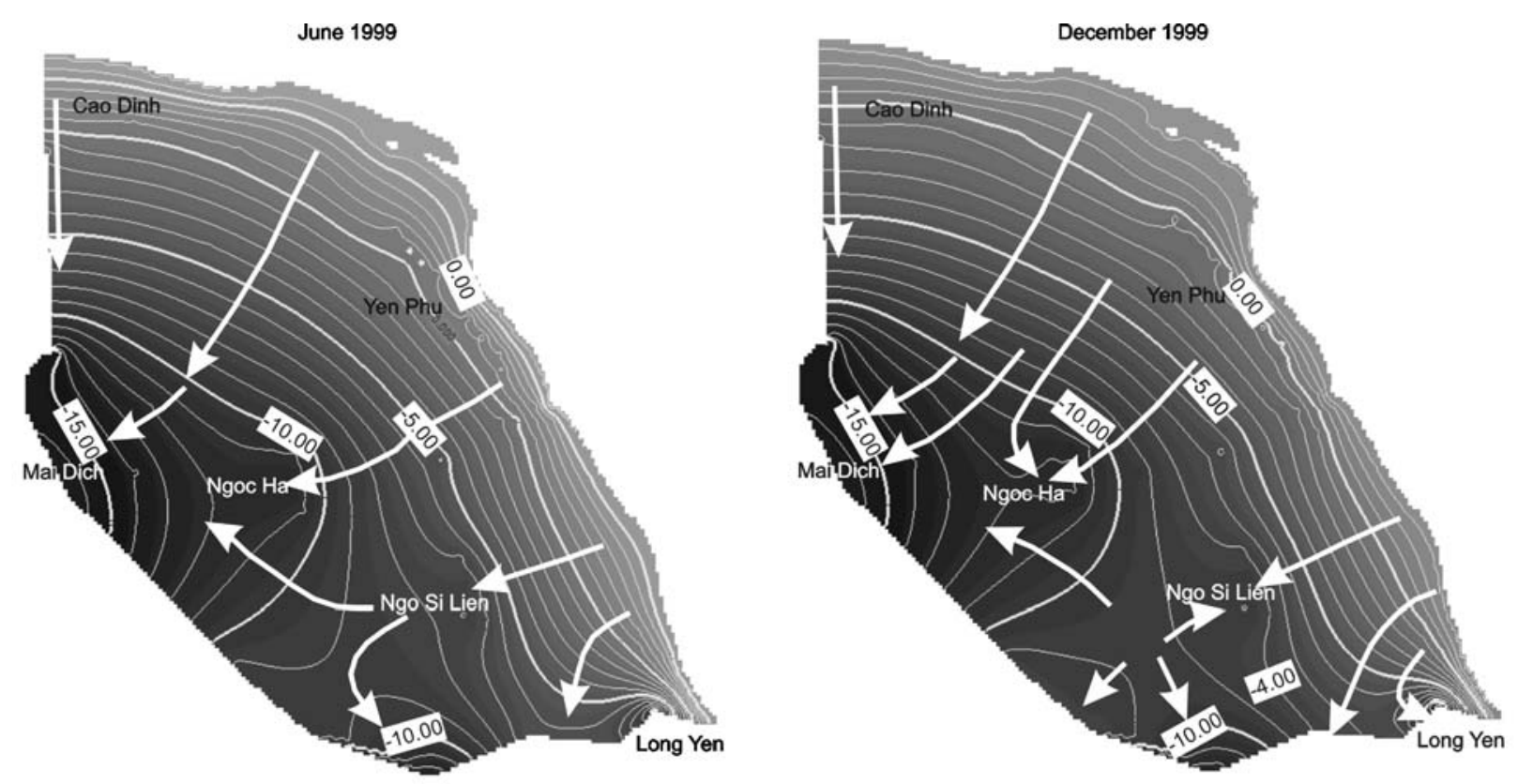

are indeed more clearly detected during the dry season than during the rainy season. The effects of the Cao Dinh, Yen Phu and Long Yen pumping fields on the piezometry are not very marked, regardless of the period of the year. The proximity of the Red River indeed allows for recharge by the river, which compensates for the pumping, resulting in a nearly constant piezometry all year round. A piezometric dome (December) or a dividing line of the groundwater flows (June) is noted to the south-west of the Ngo Si Lien pumping field. This observation is justified by the absence of pumping fields in this area.As a conclusion, the regional flow trends are barely modified inside the modelled domain from rainy to dry season: only the seasonal increase of the radius of influence of the pumping fields combined with the general lowering of the piezometry close to the Red River during the dry season are observed.

3. The calculated and observed piezometric evolutions at the observation wells close to the Red River are generally very similar (Figs. 19 and 20). Regardless of the investigated aquifer unit, piezometric head ups and downs are faithfully reproduced, with a RMS error lower than $2 \mathrm{~m}$ : this tends to demonstrate that the Red

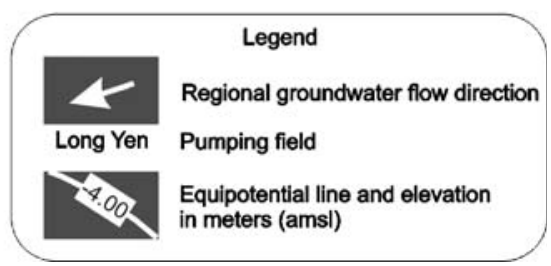

Fig. 21 Piezometric head maps, comparing the regional groundwater flow directions during the months of June (rainy season) and December (dry season) 1999 (Pleistocene aquifer, layer 5) 
River water level represents an equipotential line for the Holocene, as well as for the Pleistocene aquifers inside the modelled zone. Moreover, the heterogeneity defined for the hydrogeological units and the calibrated values of hydraulic conductivity (in the order of magnitude of $1 \mathrm{E}-04 \mathrm{~m} / \mathrm{s}$ for the aquifers and $1 \mathrm{E}-$ $08 \mathrm{~m} / \mathrm{s}$ for the silty clayey units) seem to be acceptable for reproducing realistic behaviour of the aquifers. This statement is of course true for the defined stresses and simulated period.

\section{Conclusions and perspectives}

The modelling of the groundwater flow in steady- and transient-state conditions, during the 1995-2004 period, has finally allowed for the definition of several important processes related to the regional dynamics of the shallow aquifers in Hanoi. First, the recharge process through precipitation in the modelled urban area essentially occurs through the main superficial water bodies (notably the West Lake and White Silk Lake, modelled as "windows" opened on the Holocene aquifers) and Pleistocene deposit outcrop areas. Second, values of hydraulic conductivity related to the modelled equivalent materials were estimated: an order of magnitude of $1 \mathrm{E}-08 \mathrm{~m} / \mathrm{s}$ was obtained for the silty-clayey sediments. The hydraulic conductivity of the aquifers was, on the other hand, far less constrained, as its optimal value can be between $1 \mathrm{E}-04$ and $1 \mathrm{E}-01 \mathrm{~m} / \mathrm{s}$. Third, orders of magnitude of specific storage and effective porosity could not be constrained, as the proposed model appears to be insensitive to the variation of these parameters. Fourth, the adopted conceptual hypotheses related to sedimentology, stresses and boundary conditions simulate the piezometric trends between 1995 and 2004 very satisfactorily, with time steps of 1 year or 6 months (RMS error lower than $2 \mathrm{~m}$ ). Finally, the simulations in steady- and transient-state conditions have answered the initial questions about the importance of recharge through the Red River, and have confirmed the equilibrium state between Holocene and Pleistocene aquifers close to the Red River, and moderate variation in regional flow trends depending on the season (dry or rainy).

The good quality of the results would also suggest that the sedimentological reconstruction as proposed by Jusseret et al. (Jusseret et al., as previously given, "The stratigraphical architecture of the Quaternary deposits as support for hydrogeological modelling of the central area of Hanoi (Vietnam)", unpublished report, 2008), and accordingly the spatial distribution of the hydrogeological units, is not too far from the reality. As a general conclusion, the study carried out provides the essential basis for further studies dealing with modelling of solutes (e.g. Jussel et al. 1994a, b; Vorlicek et al. 2004) or coupled modelling of groundwater flow and land subsidence processes (e.g. Dassargues and Baeteman 1994; Dassargues et al. 1993; Dassargues and Zhang 1992; Xu and Van der Gun 1995).

Acknowledgements S. Jusseret and A. Dassargues should like to express their gratitude to V.T. Tam and N.X. Khien (RIGMR) for their hospitality and welcome during the three weeks spent by the first author in Hanoi in February 2006. C. Baeteman is also thanked for her precious help, essential to the construction of the sedimentological model. The authors also acknowledge R. Hanson, P. Renard, an associate editor and an anonymous reviewer for their comments which greatly improved this article. The RIGMR should also be thanked for having kindly made its database available. Without this availability, this work could not have been accomplished.

\section{References}

Bonomi T (2009) Database development and 3D modeling of textural variations in heterogeneous, unconsolidated aquifer media: application to the Milan plain. Comput Geosci 35 (1):134-145. doi:10.1016/j.cageo.2007.09.006

Dassargues A, Zhang J (1992) Land subsidence in Shanghai: hydrogeological conditions and subsidence measurements. Bull IAEG 46:27-36

Dassargues A, Baeteman C (1994) Induced land subsidence near major river mouths; from Quaternary geology to coupled numerical models. In: Proc 7th Int IAEG Congr, Lisbon, 5-9 September 1994, Balkema, Rotterdam, The Netherlands

Dassargues A, Radu JP, Charlier R, Li XL, Li QF (1993) Computed subsidence of the central area of Shanghai. Bull IAEG 47:27-50

Faunt CC, Hanson RT, Belitz K (2008) Development of a model to assess ground-water availability in California's Central Valley. Am Water Resour Assoc Impact 10(1):27-30

Fetter CW (2001) Applied hydrogeology, 4th edn. Prentice-Hall, Upper Saddle River, NJ

Fogg GE, Noyes CD, Carle SF (1998) Geologically based model of heterogeneous hydraulic conductivity in an alluvial setting. Hydrogeol J 6(1):131-143

Foreman TL, Sharp JM Jr (1981) Hydraulic properties of a major alluvial aquifer: an isotropic, inhomogeneous system. J Hydrol 53(3-4):247-268

Funabiki A, Haruyama S, Quy NV, Hai PV, Thai DH (2007) Holocene delta plain development in the Song Hong (Red River) delta, Vietnam. J Asian Earth Sci 30:518-529

Hanson RT, Everett RR, Newhouse MW, Crawford SM, Pimentel MI, Smith GA (2002) Geohydrology of a deep-aquifer system monitoring-well site at Marina, Monterey County, California. US Geol Surv Water Resour Invest Rep 02-4003. http://pubs. usgs.gov/wri/wri024003/. Cited 09 Sept 2008

Hanson RT, Martin P, Koczot KM (2003) Simulation of groundwater/surface-water flow in the Santa Clara-Calleguas groundwater basin, Ventura County, California. US Geol Surv Water Resour Invest Rep 02-4136. http://water.usgs.gov/pubs/wri/ wri024136/text.html. Cited 09 Sept 2008

Hanson RT, Li Z, Faunt C (2004) Documentation of the Santa Clara Valley regional ground-water/surface-water flow model, Santa Clara County, California. US Geol Surv Sci Invest Rep SIR2004-5231. http://pubs.usgs.gov/sir/2004/5231/. Cited 09 Sept 2008

Haruyama S, Le QD, Le VT, Le KP, Vu VP, Hori K, Tanabe S, Saito Y (2001) Geomorphology of the Red River delta and their fluvial process of geomorphologic development, northern Vietnam. In: Haruyama S, Matsumoto J, Sakurai Y, Le QD, Le VT, Le KP (eds) Long climate change and the environment change of the lower Red River delta. Agriculture Publishing House, Hanoi

Hori K, Tanabe S, Saito Y, Haruyama S, Nguyen V, Kitamura A (2004) Delta initiation and Holocene sea-level change: example from the Song Hong (Red River) delta, Vietnam. Sediment Geol $164: 237-249$ 
Huggenberger P, Regli C (2006) A sedimentological model to characterize braided river deposits for hydrogeological applications. In: Sambrook Smith GH, Best JL, Bristow CS, Petts GE (eds) Braided rivers: process, deposits, ecology and management. Spec Publ Number 36, Int Assoc Sedimentol, Blackwell, Oxford

Jussel P, Stauffer F, Dracos T (1994a) Transport modeling in heterogeneous aquifers: 1 . statistical description and numerical generation of gravel deposits. Water Resour Res 30(6):18031817

Jussel P, Stauffer F, Dracos T (1994b) Transport modeling in heterogeneous aquifers: 2. three-dimensional transport model and stochastic numerical tracer experiments. Water Resour Res 30(6):1819-1831

Mathers S, Zalasiewicz J (1999) Holocene sedimentary architecture of the Red River delta, Vietnam. J Coast Res 15(2):314-325

Mathers S, Davies J, McDonald A, Zalasiewicz J, Marsh S (1996) The Red River delta of Vietnam: a demonstration of the applicability of sedimentology to the investigation of unconsolidated sedimentary aquifers. Br Geol Surv Tech Rep WC/96/02, British Geological Survey, Nottingham

McCloskey T, Finnemore EJ (1996) Estimating hydraulic conductivities in an alluvial basin from sediment facies models. Ground Water 34(6):1024-1032

McMahon GA, Arunakumaren NJ, Bajracharya K (2000) Hydrogeological conceptualisation of the Burdekin River delta. Hydro 2000, Proc 3rd Int Hydrol Symp Water Resour Inst Eng, Perth, Australia, 20-23 November, The Institution of Engineers, Perth

Nguyen TQ, Helm DC (1998) Land subsidence due to groundwater withdrawal in Hanoi, Vietnam. In: Borchers JW (ed) Land subsidence case studies and current research. Proceedings of the Dr. Joseph F. Poland symposium on land subsidence, Sacramento, CA, 4-5 October 1995, Star, Belmont, CA

Ponti DJ, Ehman KD, Edwards BD, Tinsley JC III, Hildenbrand T, Hillhouse JW, Hanson RT, McDougall K, Powell CL II, Wan E, Land M, Mahan S, Sarna-Wojcicki AM (2007) A 3-dimensional model of water-bearing sequences in the Dominguez gap region, Long Beach, California. US Geol Surv Open-File
Rep 2007-1013. http://pubs.usgs.gov/of/2007/1013/. Cited 09 September 2008

Saito Y, Tanabe S, Vu QL, Hanebuth TJJ, Kitamura A, Ngo QT (2004) Stratigraphy and Holocene evolution of the Song Hong (Red River) delta, Vietnam. In: Nguyen TV, Saito Y, Nguyen VQ, Ngo QT (eds) Stratigraphy of Quaternary system in deltas of Vietnam. Department of Geology and Minerals of Vietnam, Hanoi

Sharpe DR, Pugin A, Pullan SE, Gorrell G (2003) Application of seismic stratigraphy and sedimentology to regional hydrogeological investigations: an example from Oak Ridges moraine, southern Ontario, Canada. Can Geotech J 40(4):711-730

Tanabe S, Hori K, Saito Y, Haruyama S, Doanh LQ, Sato Y, Hiraide S (2003a) Sedimentary facies and radiocarbon dates of the Nam Dinh-1 core from the Song Hong (Red River) delta, Vietnam. J Asian Earth Sci 21:503-513

Tanabe S, Hori K, Saito Y, Haruyama S, Vu VP, Kitamura A (2003b) Song Hong (Red River) delta evolution related to millennium-scale Holocene sea-level changes. Quat Sci Rev 22:2345-2361

Tanabe S, Saito Y, Vu QL, Hanebuth TJJ, Ngo QL, Kitamura A (2006) Holocene evolution of the Song Hong (Red River) delta system, northern Vietnam. Sediment Geol 187:29-61

Thu TM, Fredlund DG (2000) Modelling subsidence in the Hanoi city area, Vietnam. Can Geotech J 37(3):621-637

Vorlicek PA, Antonelli R, Fabbri P, Rausch R (2004) Quantitative hydrogeological studies of the Treviso alluvial plain, NE Italy. Q J Eng Geol Hydrogeol 37(1):23-29

Xu T, Van der Gun JAM (1995) Predicting land subsidence with a constant-parameter coupled model for groundwater flow and aquitard compaction: the Markerwaard case. Proc 5th Int Symp Land Subsid, The Hague, 16-20 October 1995, Balkema, Rotterdam, The Netherlands

Yong RN, Maathuis H, Turcott E (1995) Groundwater abstractioninduced land subsidence prediction: Bangkok and Jakarta case studies. Proc 5th Int Symp Land Subsid, The Hague, 16-20 October 1995, Balkema, Rotterdam, the Netherlands 